\title{
Inflammasome-Mediated Immunogenicity of Clinical and Experimental Vaccine Adjuvants
}

\author{
Sören Reinke ${ }^{1, *(1)}$, Aneesh Thakur ${ }^{2}\left(\mathbb{D}\right.$, Cillian Gartlan ${ }^{3}\left(\mathbb{D}\right.$, Jelena S. Bezbradica ${ }^{4,+(\mathbb{C})}$ \\ and Anita Milicic $1, *,+\mathbb{D}$ \\ 1 The Jenner Institute, Nuffield Department of Medicine, University of Oxford, Oxford OX3 7DQ, UK \\ 2 Department of Pharmacy, Faculty of Health and Medical Sciences, University of Copenhagen, \\ 2100 Copenhagen, Denmark; aneesh.thakur@sund.ku.dk \\ 3 Trinity Biomedical Sciences Institute, School of Biochemistry and Immunology, Trinity College Dublin, \\ Dublin D02 R590, Ireland; gartlanc@tcd.ie \\ 4 Kennedy Institute of Rheumatology Research, Nuffield Department of Orthopaedics, Rheumatology and \\ Musculoskeletal Sciences, Medical Sciences Division, University of Oxford, Oxford OX3 7FY, UK; \\ jelena.bezbradica@kennedy.ox.ac.uk \\ * Correspondence: soren.reinke@ndm.ox.ac.uk (S.R.); anita.milicic@ndm.ox.ac.uk (A.M.) \\ + These authors contributed equally to this work.
}

Received: 25 August 2020; Accepted: 18 September 2020; Published: 22 September 2020

check for updates

\begin{abstract}
In modern vaccines, adjuvants can be sophisticated immunological tools to promote robust and long-lasting protection against prevalent diseases. However, there is an urgent need to improve immunogenicity of vaccines in order to protect mankind from life-threatening diseases such as AIDS, malaria or, most recently, COVID-19. Therefore, it is important to understand the cellular and molecular mechanisms of action of vaccine adjuvants, which generally trigger the innate immune system to enhance signal transition to adaptive immunity, resulting in pathogen-specific protection. Thus, improved understanding of vaccine adjuvant mechanisms may aid in the design of "intelligent" vaccines to provide robust protection from pathogens. Various commonly used clinical adjuvants, such as aluminium salts, saponins or emulsions, have been identified as activators of inflammasomes - multiprotein signalling platforms that drive activation of inflammatory caspases, resulting in secretion of pro-inflammatory cytokines of the IL-1 family. Importantly, these cytokines affect the cellular and humoral arms of adaptive immunity, which indicates that inflammasomes represent a valuable target of vaccine adjuvants. In this review, we highlight the impact of different inflammasomes on vaccine adjuvant-induced immune responses regarding their mechanisms and immunogenicity. In this context, we focus on clinically relevant adjuvants that have been shown to activate the NLRP3 inflammasome and also present various experimental adjuvants that activate the NLRP3-, NLRC4-, AIM2-, pyrin-, or non-canonical inflammasomes and could have the potential to improve future vaccines. Together, we provide a comprehensive overview on vaccine adjuvants that are known, or suggested, to promote immunogenicity through inflammasome-mediated signalling.
\end{abstract}

Keywords: inflammasome; adjuvant; vaccine; immunogenicity; NLRP3; NLRC4; AIM2; pyrin; non-canonical; caspase-1

\section{Introduction}

In the development of modern vaccines, adjuvants play a pivotal role as they can enhance protective immunity and usually provide an improved safety profile in comparison to live attenuated vaccines [1]. As early as 1924, Gaston Ramon described the first vaccine adjuvants, which enhanced the immune response to diphtheria and tetanus vaccines [2]. In addition to augmenting the immune response in 
general, adjuvants can also allow vaccine dose sparing - which would enable to increase global vaccine supply, reduce the number of immunisations, enhance vaccine efficacy in immuno-compromised individuals, such as young children with a developing immune system and the elderly, or broaden the immune response against highly variable pathogens, e.g., influenza [3]. Of note, vaccine adjuvant design and choice should always specifically address the targeted pathogen in order to activate the appropriate specific pathways. Thus, adjuvants qualitatively and quantitatively direct the immune system to initiate a pathogen-specific response. Today, a broad range of compounds such as mineral salts, water and oil emulsions, saponins, liposomes, microparticles and pattern recognition receptors (PRR)/Toll-like receptors (TLR) agonists are known for their adjuvanticity [4]. Although different adjuvants have diverse modes of action (MoA) in promoting immunity (reviewed in [5]), the common feature is to foster activation of innate immune cells, such as dendritic cells (DCs), monocytes, macrophages or neutrophils in order to boost activation of T- and B-cells, which are then able to mediate robust and long-lasting immunity against a specific pathogen. In this context, adjuvants can primarily perform one or more of several functions [5]: (I) creating a depot effect to maintain the release of antigen at the site of injection, (II) boosting the secretion of cytokines and chemokines, (III) enhancing the recruitment of innate immune cells at the site of injection, (IV) stimulating antigen uptake by antigen presenting cells (APCs), (V) enhancing APC maturation/expression of major histocompatibility complex (MHC) class II and co-stimulatory molecules and migration to draining lymph nodes (dLN) and, importantly, (VI) activating the inflammasome, which is the main focus of this review. An overview of inflammasome-activating adjuvants can be found in Table 1.

Table 1. Overview of inflammasome-activating adjuvants.

\begin{tabular}{|c|c|c|c|}
\hline Adjuvant & Description & Targeted Inflammasome & References \\
\hline $\mathrm{Al}(\mathrm{OH})_{3}, \mathrm{AlPO}_{4}$ & $\begin{array}{l}\text { Al-hydroxide, Al-phosphate } \\
\text { individually or as part of AS04 }\end{array}$ & NLRP3 & $\begin{array}{c}{[6-10]} \\
{[11-15]^{1}}\end{array}$ \\
\hline MF59 & Squalene $\mathrm{O} / \mathrm{W}$ emulsion & NLRP3 & $\begin{array}{l}{[16,17]^{2}} \\
{[15,18]^{3}}\end{array}$ \\
\hline $\begin{array}{l}\text { AS01 } \\
\text { AS02 }\end{array}$ & $\begin{array}{c}\text { QS-21 + MPL + liposomes } \\
\text { QS-21 + MPL + O/W emulsion }\end{array}$ & NLRP3 & {$[19-21]^{4}$} \\
\hline AS03 & Squalene $\mathrm{O} / \mathrm{W}$ emulsion + vitamin $\mathrm{E}$ & NLRP3 & 5 \\
\hline AS04 & $\begin{array}{l}\text { MPL adsorbed onto } \mathrm{Al}(\mathrm{OH})_{3} \text { or } \\
\mathrm{AlPO}_{4}\end{array}$ & NLRP3 & $\begin{array}{l}{[6-10]^{6}} \\
{[22]^{7}}\end{array}$ \\
\hline GLA-SE & GLA + squalene $\mathrm{O} / \mathrm{W}$ emulsion & NLRP3, Non-canonical & [23] \\
\hline QS-21 & $\begin{array}{l}\text { Triterpene saponin fraction purified } \\
\text { from Quillaja saponaria }\end{array}$ & NLRP3 & [19-21] \\
\hline ISCOM, IMX & $\begin{array}{l}\text { Immunostimulating complex } \\
\text { containing saponins, phospholipids } \\
\text { and cholesterol }\end{array}$ & NLRP3 & {$[24,25]$} \\
\hline CpG-ODN & $\begin{array}{l}\text { TLR9 agonist (putative } \\
\text { inflammasome-activator) }\end{array}$ & NLRP3 & [26] \\
\hline $\mathrm{Ca}_{3}\left(\mathrm{PO}_{4}\right)_{2}$ & Calcium phosphate & NLRP3 & {$[27,28]$} \\
\hline TDB & $\begin{array}{l}\text { Synthetic trehalose- } 6,6^{\prime} \text {-dibehenate } \\
\text { (an analogue of mycobacterial cord } \\
\text { factor trehalose- } 6,6^{\prime} \text {-dimycolate) }\end{array}$ & NLRP3 & {$[29,30]$} \\
\hline PLGA & $\begin{array}{c}\text { Poly(lactic-co-glycolic acid) } \\
\text { microparticles }\end{array}$ & NLRP3 & [31] \\
\hline
\end{tabular}


Table 1. Cont.

\begin{tabular}{|c|c|c|c|}
\hline Adjuvant & Description & Targeted Inflammasome & References \\
\hline Vault NPs & $\begin{array}{l}\text { Large cytoplasmic } \\
\text { ribonucleoprotein particles }\end{array}$ & NLRP3 & [32] \\
\hline Chitosan & $\begin{array}{l}\text { Biodegradable cationic polymer } \\
\text { obtained from chitin }\end{array}$ & NLRP3 & {$[10,33-36]$} \\
\hline Silica particles & Biocompatible particles & NLRP3 & {$[37,38]$} \\
\hline Gold NPs & Gold nanoparticles & NLRP3 & [39] \\
\hline Flagellin & $\begin{array}{l}\text { Used as recombinant protein, or } \\
\text { encoded in virus replicon or DNA } \\
\text { plasmid }\end{array}$ & NLRC4 & {$[40-44]$} \\
\hline DNA vaccines & $\begin{array}{l}\text { DNA plasmids or Aim2 encoded in } \\
\text { vector as immunopotentiator }\end{array}$ & AIM2 & [45-47] \\
\hline СТВ & $\begin{array}{c}\text { Cholera toxin B from Vibrio cholerae, } \\
\text { added to an Ag, or as a DNA } \\
\text { vaccine }\end{array}$ & NLRP3, Pyrin & {$[48-50]$} \\
\hline oxPAPC & $\begin{array}{l}\text { Oxidized } \\
\text { 1-palmitoyl-2-arachidonoyl-sn- } \\
\text { glycero-3-phosphorylcholine } \\
\text { (generated during tissue damage) }\end{array}$ & Non-canonical & {$[51-53]$} \\
\hline \multicolumn{4}{|c|}{$\begin{array}{l}{ }^{1} \text { These studies suggest that the NLRP3 inflammasome is dispensable for the adjuvanticity of Al salts. }{ }^{2} \text { These } \\
\text { studies found indications that NLRP3 might be involved in the MoA of MF59 (induction of expression of caspase-1, } \\
\text { IL-1 } \beta \text {, and IL-1R1). }{ }^{3} \text { These studies suggest that the NLRP3 inflammasome is dispensable for the adjuvanticity of } \\
\text { MF59. }{ }^{4} \text { These studies used components of AS01/AS02: QS-21 + MPL [20]; QS-21 formulated in liposomes [19,21]. }{ }^{5} \\
\text { AS03 is listed as a putative activator of NLRP3, since other squalene O/W emulsions (MF59, GLA-SE) have been } \\
\text { suggested as potential inflammasome activators. }{ }^{6} \text { These studies used components of AS04 (Al salts). }{ }^{7} \text { This study } \\
\text { showed enhanced adjuvanticity of AS04 compared to Al salts (increased NLRP3 activation through MPL mediated } \\
\text { TLR4 priming is a potential explanation). Abbreviations: aluminium (Al), oil-in-water (O/W), adjuvant system (AS), } \\
\text { antigen (Ag), glucopyranosyl lipid adjuvant-stable emulsion (GLA-SE), nano particles (NPs), immunostimulating } \\
\text { complex (ISCOM), ISCOMATRIX (IMX), poly(lactic-co-glycolic acid) (PLGA), trehalose-6,6'-dibehenate (TDB), } \\
\text { cholera toxin B (CTB), oxidized phospholipids (oxPAPC), absent in melanoma } 2 \text { (AIM2), nucleotide-binding } \\
\text { oligomerization domain, leucine rich repeat and pyrin domain containing protein } 3 \text { (NLRP3), NLR family CARD } \\
\text { domain-containing protein } 4 \text { (NLRC4), CpG oligodeoxynucleotide (CpG-ODN); 3-O-desacyl-4'-monophosphoryl } \\
\text { lipid A (MPL); Quillaja Saponaria fraction } 21 \text { (QS-21). }\end{array}$} \\
\hline
\end{tabular}

Inflammasomes are cytosolic multiprotein signalling platforms that drive the activation of inflammatory caspases [54]. 'Canonical' inflammasome complexes are made of specialised (germline-encoded) PRRs that couple to the effector enzyme pro-caspase-1, typically via adaptor molecule called apoptosis speck-like protein containing a caspase activation and recruitment domain (ASC) [55]. Best characterised PRRs that make up 'canonical inflammasomes' are nucleotide-binding domain, leucine-rich repeat receptor (NLR) family, pyrin domain containing 1 (NLRP1); NLR family, pyrin domain containing 3 (NLRP3); NLR family, caspase activation and recruitment domain containing 4 (NLRC4); absent in melanoma 2 (AIM2), and pyrin. There is also a 'non-canonical' inflammasome, made of inflammatory caspase- 11 in mice, and caspase- 4 or -5 in humans [55]. In general, inflammasomes recognise diverse pathogen-associated molecular patterns (PAMPs), danger-associated molecular patterns (DAMPs), or the loss of cellular homeostasis. All canonical inflammasomes drive a common downstream response: activation of pro-caspase- 1 to cleave pro-inflammatory cytokines interleukin-1 beta (IL-1 $\beta$ ) and IL-18 and induce the secretion of their active forms. Activated caspase-1 also cleaves a pore-forming protein Gasdermin D (GSDMD), to create a large plasma membrane pore in the cell in which the inflammasome was activated. GSDMD pore allows rapid release of IL-1 $\beta$ and IL-18, causes cell swelling and ultimately leads to a pro-inflammatory form of cell death, called pyroptosis. Pyroptosis releases more DAMPs and alarmins, including IL- $1 \alpha$, and sustains the inflammatory reaction (Figure 1). 


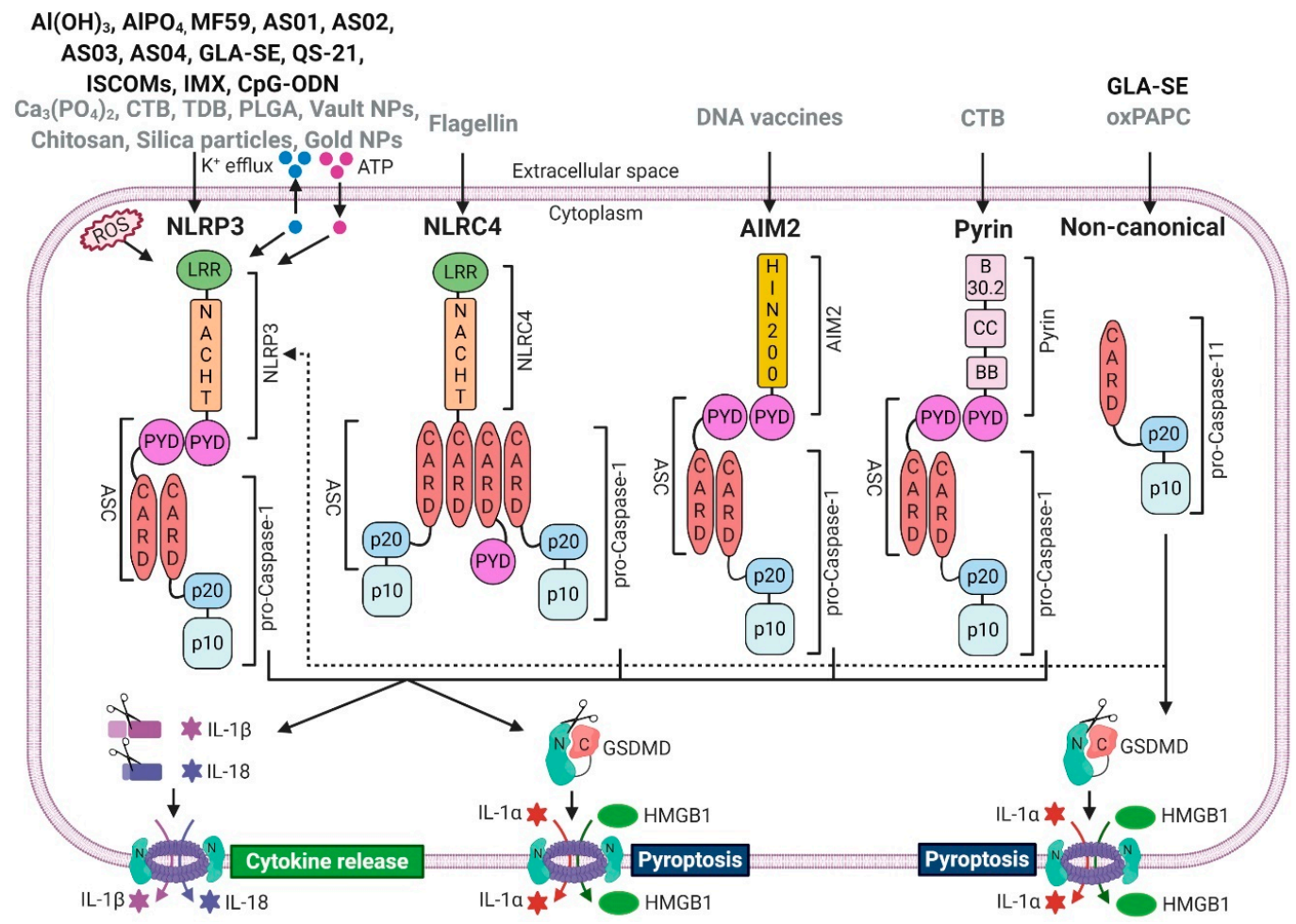

Figure 1. Vaccine adjuvants can activate inflammasomes. Clinically approved (black) and experimental (grey) vaccine adjuvants induce (or possibly induce) assembly and activation of canonical(NLRP3, NLRC4, AIM2, Pyrin) and non-canonical (caspase-11 in mice, caspase-4/5 in humans) inflammasomes. Canonical inflammasomes recruit caspase- 1 via the adaptor molecule ASC, which leads to proximity-induced auto-processing and activation of caspase-1, resulting in cleavage of pro-IL-1 $\beta$ and pro-IL-18 as well as the secretion of their mature forms. Activated caspase-1 also cleaves and activates GSDMD, resulting in pore formation and pyroptosis, which mediates the release of pro-inflammatory DAMPs such as IL- $1 \alpha$ or HMGB1. Caspase-11 cleaves GSDMD and induces pyroptosis, but it does not process pro-IL-1 $\beta$ or pro-IL-18. However, non-canonical inflammasomes activate the NLRP3 inflammasome, which indirectly induces the maturation and secretion of IL-1 $\beta$ and IL-18 via the non-canonical route. Abbreviations: apoptosis-associated speck-like protein containing a CARD (ASC), caspase recruitment domain (CARD), pyrin domain (PYD), high-mobility group box 1 (HMGB1), leucine-rich repeat (LRR), domain present in NAIP, CIITA, HET-E, and TP1 (NACHT), gasdermin D (GSDMD), reactive oxygen species (ROS), adenosine triphosphate (ATP), coiled-coil (CC), exon B30.2 domain (B30.2), B-box-type zinc finger domain (BB); immunostimulating complex (ISCOM); ISCOMATRIX (IMX). Created with BioRender.com (Toronto, Canada).

Many synthetic adjuvants activate inflammasomes, typically in myeloid cells of the innate immune system. The best characterised inflammasome, NLRP3, is also the most common adjuvant target [56]. NLRP3 expression is induced in myeloid cells via nuclear factor kappa-light-chain-enhancer of activated B-cells (NF-kB) signalling [57], upon recognition of microbial ligands, such as lipopolysaccharide (LPS) or its synthetic mimics. The activation of NLRP3 inflammasome is then triggered upon the loss of cellular homeostasis, for example after membrane damage caused by microbial pore-forming toxins, membrane permeabilising saponins, or during uptake of crystalline compounds such as aluminium crystals or uric acid crystals [58]. NLRP3 can also be activated during local tissue damage upon sensing of DAMPs such as extracellular adenosine triphosphate (ATP), accumulation of reactive oxygen species (ROS) or changes in cell volume [58,59]. NLRP3 does not recognise all of the above signals directly, rather it detects a common downstream consequence of cell damage, such as the efflux of potassium ions, or disruption of the trans Golgi network [60,61]. Unlike NLRP3, other inflammasomes directly recognise specific microbial ligands. For example, NLRC4 detects 
bacterial flagellin in the cytosol, and it has been assessed as the target of flagellin-adjuvanted vaccines (either admixed or fused to the antigen) [62]. AIM2 detects cytosolic double stranded DNA, and has been identified as a sensor of DNA vaccines [46]. The non-canonical inflammasome, pro-caspase-11, detects cytosolic lipopolysaccharide (LPS) (during infection) or oxidated membrane lipid oxidized 1-palmitoyl-2-arachidonoyl-sn-glycero-3-phosphorylcholine (oxPAPC) (generated during tissue damage) [63]. It also cleaves GSDMD to create the membrane pore and, as a result of potassium efflux, indirectly activates NLRP3 and caspase- 1 to cleave IL-1 $\beta$ and IL-18 [63]. Pro-caspase-11 has been assessed as adjuvant target of emulsion-based vaccines [23]. In this review, we will cover adjuvanticity of inflammasome-activating substances with a focus on clinically relevant adjuvants.

\section{Inflammasome-Mediated Activation of Adaptive Immunity}

To understand how inflammasome activating adjuvants can enhance vaccine immunogenicity, it is fundamental to identify the mechanisms of the inflammasome-induced innate signal transduction to adaptive immunity, which eventually leads to pathogen-specific protection. An excellent review by Evavold \& Kagan [64] describes how bridging of innate and adaptive immunity via inflammasome signalling is characterised by two elementary features: (1) maturation of innate APCs, which in turn initiate T-cell mediated responses, and (2) secretion of cytokines and chemokines to induce a specific immunological programme [64-66]. APC maturation includes antigen loading on MHC molecules, expression of the co-stimulatory molecules CD80 and CD86, and the upregulation and secretion of stimulatory cytokines such as IL-12, which is secreted by DCs to initiate Th1 responses [64,67-70]. These mechanisms can be seen as a 'direct bridge' from innate to adaptive immunity to initiate differentiation of naïve T-cells into effector and memory cells [64]. Additionally, inflammasome-induced activation of adaptive immunity is realised through an 'indirect route' via secretion of inflammasome-dependent cytokines, IL-1 $\beta$ and IL-18. Inflammasome-activated pyroptotic cells also release potent DAMPs such as ATP or high mobility group box 1 (HMGB-1) as well as the pro-inflammatory cytokine IL-1 $\alpha$ to sustain inflammation. Even though inflammasome-driven cell death eventually terminates cytokine release, recent studies suggest that in some cases, upon inflammasome activation, IL-1 $\beta$ can be released through GSDMD pores from living cells, without pyroptosis, which might represent a novel mechanism for constant and long-lasting secretion of this cytokine [51,71].

IL- $1 \alpha$ and IL-1 $\beta$ signal via interleukin-1 receptor type 1 (IL-1R1). As IL- $1 \alpha$ and IL-1 $\beta$ use the identical receptor, different outcomes depend on the context of their release rather than on ligand-specific effects [72]. IL-1R1 signalling sustains pro-inflammatory innate immune responses by further promoting innate signalling via NF-kB, inducing expression of inflammatory cytokines and chemokines, endothelial adhesion molecules, and leukocyte recruitment [73]. IL-1R1 drives adaptive responses by several mechanisms, including: (I) survival of naïve T-cells through induction of transient IL-2 release, (II) upregulation of the IL-2R, which further enhances survival and proliferation of naïve T-cells, (III) expansion of naïve and memory T-cells and increase of antibody production of B-cells through prolonged T-cell help, (IV) reduction of tolerance through expansion of conventional T-cells in the presence of regulatory T-cells (Tregs), (V) inhibition of cell death in T-cells through the downregulation of Fas ligand, and (VI) differentiation from naïve T-cells into Th17 cells [64,74-82]. Even in the absence of CD28 co-stimulation, IL-1 $\beta$ potently drives the differentiation into IL-17/IFN- $\gamma$ double-producing T-cells (Th17) $[83,84]$ suggesting that IL-1 $\beta$ inducing adjuvants may foster vaccine immunogenicity against pathogens that require Th17 responses, such as pneumococcal or fungal infections. Thus, caspase-1-dependent IL-1 release plays an important role in the transition from innate to adaptive immunity, which is a prerequisite for effective vaccine adjuvants (Figure 2).

IL-18 signals via the IL-18R, which in combination with IL-12 initiates production of IFN- $\gamma$ in NK cells, innate lymphoid type-1 cells (ILC1), and Th1 cells, eventually leading to enhanced differentiation into type-I immunity [64,85-93]. In the context of adjuvants, IL-18 also mediates antigen-specific CD8 T-cell responses [25,94] (Figure 2). The functions of IL-18 signalling are not always proinflammatory, 
and depending on the cytokine milieu and genetic background, IL-18 can also promote T helper type 2 (Th2) differentiation in the presence of T-cell receptor activation [95].

Caspase-1 cleaves and thereby inactivates IL-33. IL-33 receptor Interleukin-1 receptor-like 1 (ST2) is expressed on innate and adaptive cells, such as alternatively-activated macrophages, type 2 innate lymphoid cells (ILC2), Th2 cells, and Tregs. IL-33 drives Th2 polarisation and tissue repair responses [73], and thus by inactivating IL-33, inflammasomes generally block type-2 responses (Figure 2). IL-33 also augments CD8 T-cell responses by affecting their proliferative and cytotoxic activity [96]. In B-cells, IL-33 mediates B-cell activation of B-1 type cells for enhanced IgM production [97] and also functions as a cell-intrinsic regulator of fitness during the early development of B-cells [98].

Not all inflammasome substrates are pro-inflammatory. IL-37 is known to reduce LPS-induced production of IL-1 $\beta$ and tumor necrosis factor alpha (TNF- $\alpha$ ) in vitro and thus may have a role in shaping the immune response to adjuvants through inhibition of mitogen-activated protein kinase and NF-kB transcription $[99,100]$. In support of this, mice expressing human IL-37 transgene developed lower inflammation and were protected from LPS challenge [101]. IL-37 is a less well understood inflammasome substrate, because human IL-37 lacks the mouse orthologue that would enable in-depth genetic and functional studies.

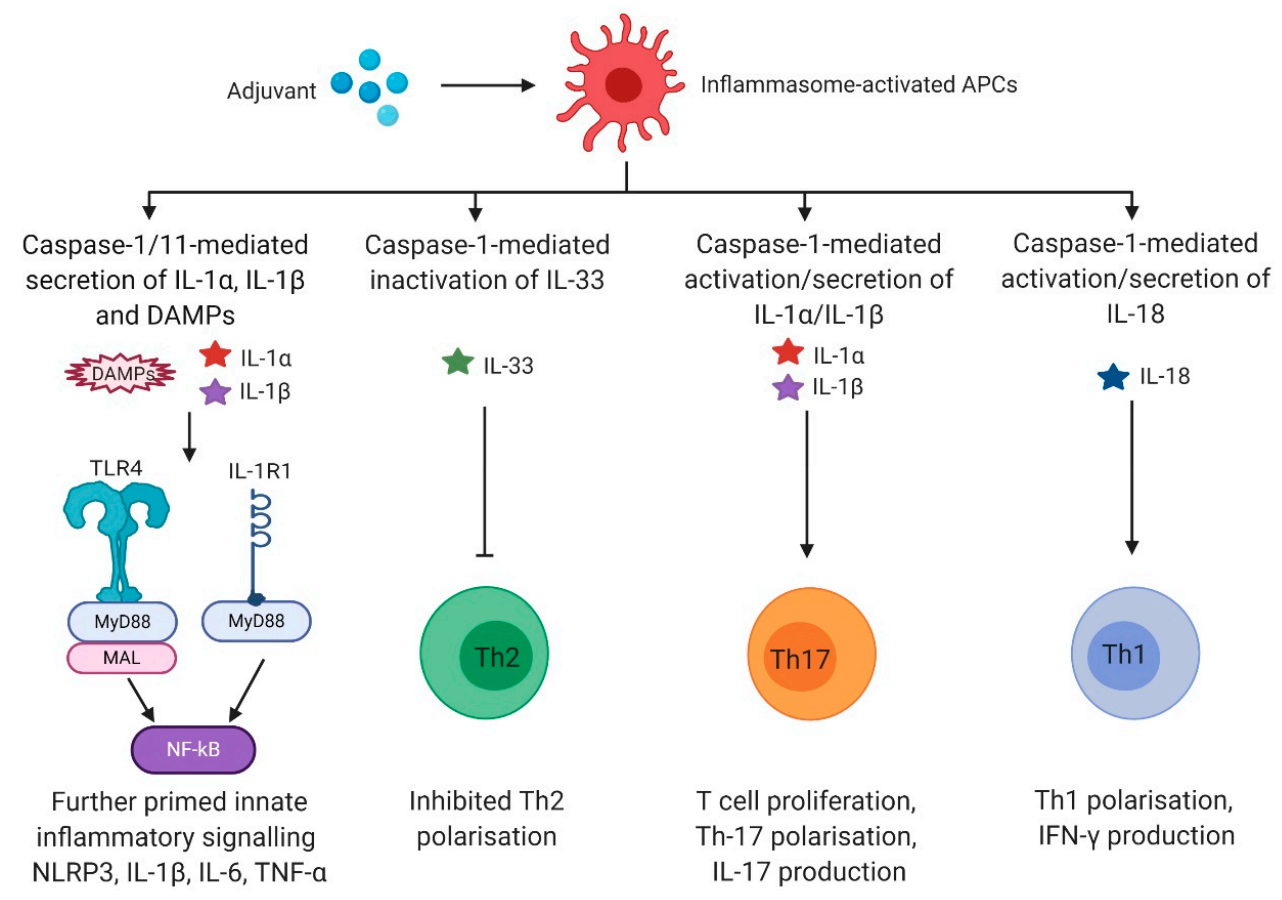

Figure 2. Caspase-1-dependent cytokines activate adaptive immunity. IL- $1 \alpha$ and IL-1 $\beta$ signalling via IL-1R1 activates the pro-inflammatory transcription factor NFKB via the MyD88 pathway. In addition, caspase-1 induces NFKB activation through the cleavage of MAL [102]. NFKB activation results in the production of various pro-inflammatory cytokines such as IL- 6 or TNF- $\alpha$, which (I) enhances innate and adaptive immune responses and (II) provides a further priming signal for robust inflammasome-mediated signalling. Cleavage and inactivation of the potent Th2 driver IL-33 by active caspase- 1 blocks Th2 polarisation. Mature IL- $1 \alpha$ and IL- $1 \beta$ directly affect lymphoid cells by promoting differentiation from naïve T-cells into Th17 cells, T-cell survival, or increased antibody production of B-cells through prolonged T-cell help. After caspase-1-mediated activation, IL-18 binds IL-18R and thereby initiates the production of IFN- $\gamma$ eventually inducing enhanced differentiation into Th1 type immune cells. Abbreviations: antigen presenting cells (APCs), danger-associated molecular pattern (DAMP), Toll-like receptor (TLR), interleukin 1 receptor 1 (IL-1R1), myeloid differentiation primary response 88 (MyD88), Myd88 adapter-like (MAL), nuclear factor kappa-light-chain-enhancer of activated B-cells (NFKB), nucleotide-binding oligomerisation domain, leucine rich repeat and pyrin domain containing protein 3 (NLRP3). Created with BioRender.com (Toronto, Canada). 
Together, the caspase-1-dependent cytokines have been shown to influence both the humoral and cellular arms of adaptive responses, and thus may be of relevance for immunogenicity provided by inflammasome-activating adjuvants. Inflammasomes may be of particular interest for vaccines targeting cell-mediated immunity [56], as this arm of immune response is the direct place of action for inflammasome-dependent cytokines.

\section{Clinically Relevant NLRP3-Activating Adjuvants}

\subsection{Aluminium Salt-Based Adjuvants}

Aluminium (Al) salts, usually referred to as 'alum', were the first reported clinical adjuvants and were widely used long before the inflammasome was discovered by Jürg Tschopp and colleagues [54]. Chemically, alum is a hydrated sulphate salt of aluminium, originally employed in antigen (Ag) precipitation and not used as an adjuvant today. However, in the context of vaccine adjuvants, the typically used salts Al-hydroxide and Al-phosphate are commonly referred to as 'alum', often without making a distinction on the type of salt used. This, in part, is the reason for the ongoing ambiguity in understanding the MoA of Al-based adjuvants [103]. Al-salts are usually associated with the antigen through electrostatic attraction, hydrophobic attraction or ligand exchange [104].

In terms of MoA, one of the most studied Al-based adjuvants is Imject, a commercial adjuvant developed by Thermo Scientific, a formulation comprising Al-hydroxide and Mg-hydroxide. In a study in 2008, NLRP3 was identified as a sensor for Imject crystal-induced lysosomal damage, in vitro, albeit requiring LPS-induced priming via TLR4 for robust IL-1 $\beta$ secretion [7].

Three independent studies showed strongly diminished immunogenicity in NLRP3 ${ }^{-/}$mice after immunisation with Imject-adjuvanted Ovalbumin (OVA) [6,8,9]. Two studies suggested that macrophages and mast cells sense both Imject and Alhydrogel (Al-hydroxide, developed by Brenntag, Germany) [13], inducing the release of host DNA serving as DAMP that mediates the adjuvant activity [12]. However, a more recent study highlighted differences in the immunostimulatory properties between Imject, Alhydrogel, and an alum-precipitated Ag, bringing into question the extrapolation of Imject data to the clinically used Al-adjuvants [105]. A study using human serum albumin (HSA) as the antigen found that the NLRP3 inflammasome is dispensable for the adjuvant activity of Al-hydroxide [11]. Later studies confirmed that Al-hydroxide adjuvanticity is independent of NLRP3 and caspase-1 in OVA immunisation models [12-14], with further in vitro studies reporting that crystalline structures such as Al-hydroxide or uric acid cross-link DC membrane lipids, activating the spleen tyrosine (Syk) kinase, and mediating adjuvanticity in an inflammasome-independent fashion [106,107].

Differential results may result from divergent environmental conditions such as the presence of diverse microbiome patterns, which are known to interact with inflammasomes [108]. In addition, the use of different Al-hydroxide compositions in varying concentrations may result in altered adaptive immune responses. Although a divide remains on the ability of Al-hydroxide to activate the NLRP3 inflammasome in vivo, there is growing evidence that the NLRP3 inflammasome is dispensable for high-level antibody responses induced by Al-hydroxide [15]. In humans, IL-1 $\beta$ blockade using canakinumab did not reduce antibody responses to Al-hydroxide-adjuvanted meningococcal vaccine (Menjugate $^{\mathrm{TM}}$, GSK, Sienna, Italy) in healthy volunteers [109]. Thus, Al-hydroxide has a questionable benefit in meningococcal conjugate vaccines and today the licensed quadrivalent meningococcal conjugate vaccines do not contain Al adjuvants [110].

In addition to the 'classic' Al-salt based adjuvants, structurally-modified Al particles are being assessed for their ability to activate NLRP3. Recently, Sun et al. generated 'aluminium oxyhydroxide nanorods' with a defined surface functionalisation and charge, which enhanced NLRP3 activation in vitro and increased antibody production in an OVA immunisation model, compared to Al-hydroxide microparticles [111]. Al (oxy)hydroxide nanoparticles increase the production of uric acid and thereby enhance NLRP3 activation compared to microparticles, further indicating a relevance of physical 
characteristics for the adjuvanticity of $\mathrm{Al}$ particles [112]. In line with this, Orr et al. demonstrated that, compared to the conventional Al-hydroxide adjuvant (Alhydrogel), consisting of aggregates of particles in various sizes, newly developed stable nanoparticles ("nanoalum") provide improved immunogenicity against lethal influenza challenge in mice [113], dependent on NLRP3, ASC, and IL-18R.

Of note, an earlier study already demonstrated that only positively-charged particulate vaccine adjuvants such as Al-hydroxide (Alu-Gel-S) or polymer-chitosan nanoparticles (CNPs) activate the NLRP3 inflammasome [10]. Together, these results indicate that the full potential of Al-salt-based adjuvants is not yet reached, as physical modification of the size or shape might improve adjuvanticity, possibly through enhanced activation of the NLRP3 inflammasome.

Al hydroxide is also used in combinatorial adjuvant systems such as AS04 in order to target multiple pathways $[103,114,115]$. In the licenced vaccines against the human papillomavirus (HPV, Cervarix ${ }^{\mathrm{TM}}$ GSK, Rixensart, Belgium) and hepatitis B virus (HBV, Fendrix ${ }^{\mathrm{TM}}$, GSK, Rixensart, Belgium), AS04 consists of 3-O-desacyl-4'-monophosphoryl lipid A (MPL-A), an LPS-derivative that activates TLR4, adsorbed onto Al-hydroxide [115]. Inclusion of MPL-A induces robust TLR4 mediated NFKB activation, resulting in APC activation, production of the NFKB targets TNF- $\alpha$ and IL-6, and Ag-specific T-cell activation [115]. Targeting TLR4 via MPL-A improved clinical applications, as AS04-adjuvanted HPV and HBV vaccines induced higher antibody responses compared to vaccines adjuvanted with Al-hydroxide alone $[22,103,116]$. Since TLR priming represents a prerequisite for robust inflammasome activation in vitro, it may seem plausible that TLR4 priming by MPL-A also enhances inflammasome activation in vivo. However, whether AS04 provides improved vaccine responses through increased NLRP3 activation remains to be assessed.

\subsection{Saponin-Based Adjuvants}

Saponins have been recognised as vaccine-adjuvanting substances for several decades [117]. Their adjuvanticity is based on disrupting the membrane integrity and the induction of danger signals $[114,118]$. The most widely used substance from the saponin family is QS-21, a specific triterpene saponin fraction purified from Quillaja saponaria. Adjuvant systems AS01 and AS02, developed by GSK, contain QS-21 in combination with the TLR4 agonist MPL-A and liposomes, or MPL-A in an oil-in-water emulsion, respectively [119]. AS01 especially is of clinical relevance, as part of the malaria vaccine Mosquirix ${ }^{\mathrm{TM}}$ (currently in pilot introduction in Africa, GSK, Rixensart, Belgium) and the licenced vaccine against herpes zoster, Shingrix ${ }^{\mathrm{TM}}$ (GSK, Rixensart, Belgium). Recently, Marty-Roix et al. clearly demonstrated that clinical grade QS-21 activates the NLRP3 inflammasome in an ASC-, TLR4-, myeloid differentiation primary response 88 (MyD88)-, and TIR-domain-containing adapter-inducing interferon- $\beta$ (TRIF)-dependent manner in murine bone marrow-derived DCs (BMDCs) and suggested phagocytosis, followed by lysosomal acidification, as a possible mechanism [20]. Furthermore, they showed that caspase 1/11 double-deficient BMDCs and macrophages exhibit strongly reduced IL-1 $\beta$ secretion upon stimulation with QS-21. These results raise the question whether QS-21 targets the NLRP3/caspase-1 axis directly or via the non-canonical inflammasome (caspase 11 in mice, caspase $4 / 5$ in humans), which induces NLRP3-dependent caspase- 1 activation by promoting potassium efflux [120-122]. Importantly, QS-21-mediated NLRP3 activation requires co-stimulation with MPL-A, indicating that TLR priming is a prerequisite for robust inflammasome activation by QS21 in vitro [20]. In contrast, in vivo immunization with QS-21-adjuvanted HIV-1 gp120 showed that QS-21 indeed enhances antibody and T-cell responses in mice but NLRP3 deficiency boosted these effects, indicating that NLRP3 might decrease QS-21-induced Ag-specific responses in vivo [20]. In human monocyte-derived DCs, cholesterol-dependent endocytosis of QS-21 formulated in liposomes induced lysosomal membrane permeabilisation and activated DCs in a Syk kinase- and cathepsin B-dependent manner [21]. This lysosomal destabilization may in parallel induce activation of the NLRP3 inflammasome. A further study demonstrated that immunisation with QS-21 in liposomes leads to an enrichment of QS-21 in CD169+ resident macrophages in the dLN, which activates caspase- 1 and results in innate cell recruitment, DC activation, and T-cell priming [19]. In contrast to the results of Marty-Roix 
et al. [20], T-cell responses were diminished and antibody responses were unaltered in caspase-1 deficient mice after immunisation with QS-21/liposome formulation [19]. The caspase-1-dependent adjuvanticity of QS-21 in liposomes was partially mediated through the release of HMGB1 and reliant on MyD88, indicating that TLR priming is required for robust QS-21-mediated immunogenicity in vivo. This study also used caspase-1/11 double-deficient mice, which do not allow to distinguish between canonical and non-canonical NLRP3 activation. However, membrane permeabilization and DAMP release as proposed mechanisms indicate canonical NLRP3 activation. Taken together, QS-21 is a potent activator of the NLRP3 inflammasome, although it requires additional immunostimulatory substances to exhibit its full adjuvanting potential. Hence, adjuvant systems such as AS01, in which QS-21 and MPL-A synergistically activate de novo pathways and induce robust antibody and T-cell responses, represent a sophisticated approach to improve the immunogenicity of modern vaccines [123-125].

Quil A, which is a mixture of saponins extracted from Quillaja saponaria, is a more heterogenous saponin adjuvant and is part of the immunostimulating complex-based adjuvants ISCOM and ISCOMATRIX (IMX) [24,126]. Besides Quil A, these formulations contain phospholipids and cholesterol, forming spherical, cage-like structures $40 \mathrm{~nm}$ in diameter. Vaccines formulated with these adjuvants provide long-lasting antibody responses, a balanced Th1/Th2 response, and generation of cytotoxic T-cells [127-129]. In 2011, Duewell et al. demonstrated that OVA, adjuvanted with IMX, induces high levels of IL-1 $\beta$, IL-6, granulocyte-macrophage colony-stimulating factor (GM-CSF), and IL-12p40 as well as low levels of IL-4 and IL-5 in the dLNs, which indicates early inflammasome activation and a mixed Th1/Th2 type response [24]. Furthermore, the authors verified caspase-1 dependency of OVA/ISCOM-induced IL-1 $\beta$ secretion in vitro. However, a later study assessed inflammasome activating characteristics of IMX and highlighted substantial differences between in vitro and in vivo mechanisms of vaccine adjuvants [25]. Wilson et al. observed IMX-induced IL-1 $\beta$ production in dLN in vivo and robust NLRP3-, ASC-, and caspase-1/11-dependent IL-1 $\beta$ secretion in LPS-primed thioglycollate-induced peritoneal macrophages in vitro, suggesting dependence on lysosomal destabilisation [25]. In contrast, the innate NK cell response to IMX was dependent on IL-18R but independent of NLRP3 and IL-1R1 in vivo. In line, the IL-18 pathway was crucial for IMX-OVA-induced adaptive immunity, as $I L-18^{-/-}$and $I L-18 R^{-/-}$mice showed strongly diminished levels of Ag-specific CD8 T-cells and IgG2c antibodies, while deficiency in IL-1R1 or NLRP3 had no effect on adaptive immune responses. Interestingly, TNF- $\alpha$ provided a physiological inflammasome priming signal, which might substitute for the lack of a TLR agonist in IMX. Together, this study demonstrated inflammasome-dependent and -independent IMX-induced mechanisms and raised the question of how IL-18 contributes to IMX-induced immunity in an NLRP3-independent fashion. Potentially, constitutively expressed IL-18 could be released via APC cell death at the site of injection, or alternatively other proteases such as caspase-8, able to process IL-18 [130], could substitute for inflammasome/caspase-1-mediated maturation of pro-IL-18 [25].

Recently, Cibulski et al. assessed adjuvant characteristics of alternative saponin formulations and replaced Quil A in ISCOM and IMX by fractions extracted from Quillaja brasiliensis to generate Quillaja brasiliensis fraction 90 (QB-90) and ISCOMATRIX-like Quillaja brasiliensis fraction 90 (IMXQB-90), respectively [128,131]. Inoculation of mice with QB-90 or IMXQB-90 induced antibody production, recruitment and activation of myeloid and lymphoid cells in spleen and dLN, and production of the Th1-type cytokines IFN- $\gamma$ and TNF- $\alpha$. In BMDCs, both saponin formulations induced caspase-1-dependent IL-1 $\beta$ production in vitro, which is in line with the above-mentioned studies of IMX. However, whether the inflammasome mediates the potential adjuvanticity of QB-90 or IMXQB-90 in vivo, remains elusive.

In summary, the literature clearly demonstrates that saponin-based adjuvants activate the NLRP3 inflammasome pathway to initiate an early IL-1 $\beta$ - or IL-18-mediated innate immune response, but the impact of this mechanism on adjuvanticity remains a matter of debate. Of note, saponins are usually used in combination with other components such as TLR agonist or liposomes, and the observed innate activation is likely a result of additive and/or synergistic effects of the individual components. 


\subsection{Emulsion-Based Adjuvants}

In the context of adjuvants, emulsions commonly include water-in-oil (W/O) and oil-in-water $(\mathrm{O} / \mathrm{W})$ emulsions such as the prototypes Montanide 720 and MF59, respectively $[4,132,133]$. Double emulsions such as water-in-oil-in-water $(\mathrm{W} / \mathrm{O} / \mathrm{W})$ and oil-in-water-in-oil $(\mathrm{O} / \mathrm{W} / \mathrm{O})$, able to induce biphasic responses, have also been developed for veterinary applications [134,135]. Modern clinically relevant O/W emulsions, such as MF59 and AS03 - which additionally contains $\alpha$-tocopherol (vitamin E)-use the fully metabolisable lipid squalene, produced during cholesterol synthesis in humans $[103,136]$. They have been used in vaccines against pandemic influenza H1N1 and avian influenza H5N1 [103,119] and in vaccine development for age-specific groups such as the children and elderly $[137,138]$. MF59 and AS03 have been shown to recruit $\mathrm{CD} 11 \mathrm{~b}^{+} / \mathrm{MHC}^{-\mathrm{II}^{+}}$cells and induce IL-12(p40)/IL-5 expression (MF59) or to recruit monocytes/granulocytes and induce C-C motif chemokine 2 (CCL2), CCL3, IL-6, CSF3, and C-X-C motif chemokine ligand 1 (CXCL1) (AS03) $[16,114,139,140]$. Among other cytokines and pro-inflammatory mediators, expression of the inflammasome related genes caspase- $1, I L-1 \beta$, and IL-1R1 are strongly induced by MF59 [16]. Furthermore, MF59 adjuvanticity depends on the TLR adaptor molecule MyD88 [15], and induces the release of ATP, which can activate the NLRP3 inflammasome via the P2X7 receptor [17]. Nevertheless, two independent studies demonstrated that NLRP3 is not required for the adjuvanticity of MF59, despite of the necessity for ASC, which also functions as inflammasome adaptor molecule $[15,18]$. There are no publications addressing NLRP3 inflammasome activation by the adjuvant system AS03; this might be due to the lack of appropriate TLR-mediated priming by these emulsions, since GLA-SE, a combination of the synthetic TLR4 agonist GLA and squalene oil-in-water emulsion, mediates adjuvanticity through NLRP3 activation and TLR4 signalling, inducing robust Th1 and B-cell responses [23]. In contrast, squalene oil-in-water emulsion alone induced considerably lower adjuvanticity when compared to GLA-SE [23,94]. Interestingly, besides caspase-1, GLA-SE-mediated adjuvanticity is also dependent on caspase-11, the non-canonical inflammasome [23]. Altogether, the studies above indicate that squalene oil-in-water emulsion might be an inducer of canonical and non-canonical NLRP3 inflammasome activation, if supplemented with a TLR agonist.

\subsection{TLR Agonists as Adjuvants}

TLRs represent a prominent vaccine adjuvant target due to their potent activation of MyD88 and TRIF-mediated activation of NFKB and interferon-regulatory factors. Thereby, TLR-agonists can provide the "first step" priming signal for robust NLRP3 inflammasome activation. LPS-analogues, and thus TLR4 agonists, such as MPL-A or GLA, have been used in the above mentioned combinatorial vaccine adjuvants AS01, AS02, AS04, and GLA-SE to enhance adjuvanticity of QS-21, Al particles, and squalene $\mathrm{O} / \mathrm{W}$ emulsion. Of note, in addition to TLR4, the non-canonical inflammasome represents an intracellular sensor of LPS in vivo [141], which has not yet been confirmed for MPL-A. MPL-A alone does not induce caspase- 1 activation and IL-1 $\beta$ secretion in vitro $[20,21,142]$. This is in line with LPS, which only provides transcriptional upregulation of pro-IL-1 $\beta$ and NLRP3 through priming and requires a second inflammasome stimulus for robust caspase- 1 activation, in vitro $[7,57,143]$. In contrast, LPS alone is sufficient for IL- $\beta$ secretion in vivo [141,144], which might also indicate that MPL-A is a potential inducer of IL-1 $\beta$ secretion in vivo. Interestingly, immunisation with the synthetic TLR4 agonist GLA induced the production of small amounts of IL-1 $\beta$ in vivo [23]. However, there are mechanistic differences between LPS and MPL-A, since LPS induced signalling is predominantly transmitted via MyD88, whereas MPL-A is a TRIF-biased agonist of TLR4, which might explain its reduced toxicity [145]. Taken together, MPL-A has an immunostimulatory effect and enhances adjuvanticity of combinatorial adjuvants, but it remains unclear whether it triggers the same pathway as LPS in vivo.

Among others, adjuvants targeting TLR3 (dsRNA analogues such as poly(I:C)), TLR5 (flagellin), TLR7/TLR8 (imidazoquinolines such as Imiquimod), or TLR9 (CpG oligodeoxynucleotide) have been assessed for adjuvanticity [3]. Polyinosinic:polycytidylic acid (Poly-IC) can generate a comprehensive 
immune response, which is suited for anti-viral and tumour vaccines as it activates APCs and induces memory T and B-cell production [146]. Flagellin may also provide excellent adjuvanticity as it induces cellular and humoral immune responses through activation of two signalling pathways via TLR5 and NLRC4 [62]. Similarly, TLR7/8 agonists, such as Imiquimod have been shown to activate APCs, induce humoral and cellular immunity, and especially enhance Th1 responses [147]. Despite safety concerns regarding the production of autoreactive antibodies, TLR9 agonists have been shown to induce robust immune responses to the vaccine antigen with no apparent adverse reactions [3,148], and have been clinically evaluated with a number of infectious disease and cancer vaccines [149]. This includes CpG-adjuvanted vaccines against anthrax, hepatitis B, malaria, and influenza [149]. Clinical trials using CpG in vaccines against anthrax [150,151] and HBV [152] have been especially promising as they demonstrated rapid and persistent production of protective antibodies, even in immunocompromised HIV-infected individuals [153,154]. Recently, Kim et al. showed that in vitro, CpG induces the expression of NLRP3, ASC, caspase-1, and IL-1 $\beta$ in a TLR9-dependent fashion, suggesting that the NLRP3 inflammasome could be involved in the mechanism of CpG-adjuvanted vaccines [26].

In summary, TLR agonists can enhance immunogenicity through the activation of different PRRs, eventually initiating activation of NFKB signalling, which induces a pro-inflammatory signalling cascade and may provide a priming signal for NLRP3 inflammasome activation in combinatorial adjuvants. However, in case of the TLR5 agonist flagellin, NLRC4 inflammasome activation is provided by the same single adjuvant.

\section{Experimental Adjuvants That Activate Inflammasomes}

In addition to the above inflammasome-activating adjuvants, of which the majority are commonly used in clinical applications, other substances have been assessed for inflammasome-mediated adjuvanticity. These include compounds that have been shown to activate NLRP3, NLRC4, AIM2, pyrin, and the non-canonical inflammasome.

\subsection{NLRP3 Inflammasome}

Chitosan is a biocompatible and biodegradable cationic polymer obtained from chitin [56]. It has a good safety profile and has been shown to promote adjuvanticity through induction of Ag-specific IgG1/IgG2a and Th1/Th2/Th17 responses [155]. Chitosan activates NLRP3-dependent IL-1 $\beta$ secretion in BMDCs, bone marrow-derived macrophages (BMDMs), and human peripheral blood mononuclear cells $[33,34,36]$. In addition to the NLRP3 inflammasome pathway, chitosan also activates the cyclic GMP-AMP synthase (cGAS) - stimulator of interferon genes (STING) pathway to promote cellular immunity [34]. In combination with CpG, chitosan-promoted Ag-specific Th1, Th17, and IgG2 responses were strongly dependent on the NLRP3 inflammasome in vivo [36]. Adjuvant characteristics of chitosan have also been assessed in combination with Al-salts. Chitosan-aluminium sulphate nano-particles, as well as conventional chitosan particles, induced IL-1 $\beta$ production in BMDCs in an NLRP3- and ASC- dependent manner [35].

The synthetic adjuvant trehalose-6,6'-dibehenate (TDB, an analogue of mycobacterial cord factor trehalose-6,6'-dimycolate (TDM)) [156], promotes Syk and CARD9-dependent activation of innate immunity through the C-type lectin Mincle, which mediates adjuvanticity via induction of robust Th1 and Th17 responses [157-159]. Importantly, TDB initiates NLRP3-dependent caspase-1 processing and IL-1 $\beta$ secretion in BMDCs, which relied on potassium efflux, lysosomal rupture, and ROS production [30]. Furthermore, TDB-induced recruitment of neutrophils was strongly impaired in NLRP3 ${ }^{-/}$mice [30]. A further in vivo study, which used TDB formulated into liposomes, demonstrated that TDB induces MyD88- and IL-1R1-dependent Th1/Th17 responses independent of IL-18 and IL-33 signalling [29], further supporting the NLRP3 inflammasome as an essential mediator that contributes to TDB-induced adjuvanticity. 
Calcium phosphate nanoparticles (CaP-NPs) have been demonstrated as a promising adjuvant candidate due to their ability to induce balanced Th1 and Th2 immune responses as well as their high degree of biocompatibility and biodegradability [160]. Initially, He et al. showed in a herpes simplex virus type 2 (HSV-2) challenge model that CaP-NPs induce higher titres of IgG, lower titres of IgE, and improved protection against HSV-2 compared to Al-hydroxide [161,162]. A later study demonstrated that CaP crystals induce NLRP3-, ASC-, and caspase-1-dependent secretion of IL-1 $\beta$ in vitro [28]. However, antibody responses after immunisation with another form of calcium phosphate - hydroxyapatite - particles were shown to be independent of NLRP3, ASC and caspase-1, indicating that $\mathrm{CaP}$ particles might provide NLRP3 inflammasome-independent adjuvanticity in vivo [27].

Biodegradable and non-degradable nano- and microparticles, have been used for Ag delivery and as immunopotentiators [56,163]. Biodegradable poly(lactic-co-glycolic acid) (PLGA) microparticles have been studied as vehicles for antigens (e.g., Hepatitis B surface antigen (HBsAg), tetanus toxoid, HIV gp120) and TLR-agonist adjuvants, and have been reported to induce humoral immunity through the induction of Ag-specific IgG1 and IgE $[56,164,165]$. Sharp et al. showed that PLGA induces NLRP3and caspase-1-dependent IL-1 $\beta$ release in vitro [31]. In vivo, PLGA induced IL-6 secretion and innate immune cell recruitment in an NLRP3-dependent manner, but the production of Ag-specific antibodies was independent of the NLRP3 inflammasome [31], putting the relevance of NLPR3 in PLGA-mediated adjuvanticity into question.

Biocompatible silica particles induced NLRP3-dependent IL-1 $\beta$ and HMGB release in human lung epithelial cells [38]. Furthermore, depending on the size, silica particles induced caspase-1-dependent IL-1 $\beta$ secretion in BMDMs, and IL-1 $\beta$-mediated lung inflammation in mice [37]. Interestingly, Kuroda et al. suggested that silica-induced lysosomal damage also activates the NLRP3-independent PGE2-inducing pathway, at least in addition to the NLRP3 inflammasome pathway [166].

Moreover, gold nanoparticles, which have been used in cancer vaccines [56,167,168], might also activate the inflammasome, as particles with a distinct size and shape have been shown to induce IL-1 $\beta$ and IL-18 secretion in BMDCs [39].

Taken together, the general role of NLRP3 in particle-induced (including particulate Al-adjuvants) immune responses, and especially regarding adjuvanticity in vivo, remains elusive.

Vaults, which are large cytoplasmic ribonucleoprotein particles that contain three proteins and a small untranslated RNA [32,169,170], have been shown to display self-adjuvanting properties [171-173]. Zhu et al. engineered vaults that contain the immunogenic Chlamydia trachomatis epitope PmpG-1 and showed that PmpG-1-vaults induce NLRP3-, ASC-, and caspase-1-dependent IL-1 $\beta$ secretion in human monocytic (THP-1) cells, and PmpG-1 responsive CD4 ${ }^{+}$T-cells after immunisation in mice [32]. However, whether adjuvanting vaults promote NLRP3-mediated adjuvanticity in vivo, remains unclear.

\subsection{NLRC4 Inflammasome}

The NLRC4 inflammasome is, in addition to the transmembrane receptor TLR5, an intracellular sensor of bacterial flagellin [55]. Flagellin has been positively evaluated as a broad-spectrum vaccine adjuvant capable of inducing potent systemic and mucosal adaptive immune responses [62,174]. In humans it has been shown to provide robust antigen-specific humoral immunity to influenza vaccines and is well tolerated $[175,176]$. In contrast to NLRP3, which is activated through numerous different stimuli that induce cellular stress, NLRC4 specifically senses flagellin via NLR family, apoptosis inhibitory protein 5 (NAIP5) and NAIP6. This raises the question of whether NLRC4 or TLR5 (or both) are required for robust flagellin-induced adjuvanticity rather than flagellin-mediated NLRC4 activation in general. Using Naip5 $5^{-/}$and $\mathrm{TLR}^{-/-}$mice on a C57/BL6 background, López-Yglesias et al. demonstrated that IgG2c responses against flagellin are TLR5- and NAIP5-dependent, whereas the dominant IgG1 responses were only partially dependent. Flagellin-specific IgG1 response was also mediated by a TLR5-, NAIP5-, and MyD88-independent pathway. Interestingly, flagellin induced a codominant IgG1 and IgG2a response in A/J mice. After immunisation with flagellin-adjuvanted 
OVA, mice only developed robust OVA-specific IgG1 responses, which were MyD88-dependent and independent of TLR5, NAIP5, and caspase-1. However, deficiency in both TLR5 and caspase-1 led to reduced IgG1 responses [41]. These results indicate that flagellin-induced adjuvanticity is mediated through a third TLR5- and NLRC4-independent pathway but requires at least one of the specific sensors TLR5 or NLRC4 to display its full potential. This is in line with another study that showed equal OVA- and flagellin-specific IgG1 responses between WT, TLR5 ${ }^{-/-}$, and $\mathrm{NLRC}^{-/-}$ mice, but strongly diminished antigen specific responses in TLR5/NLRC4 double-deficient mice [44]. Interestingly, flagellin could be a promising alternative to NLRP3-activating adjuvants in vaccines for immunocompromised patients, as it properly induces inflammasome activation in DCs from HIV patients that harbour intrinsic NLRP3 defects [177]. Flagellin has also been assessed for adjuvanticity after administration of a recombinant modified vaccinia virus Ankara (rMVA) vaccine encoding the flagellin gene. Immunisation with rMVA-flagellin induced enhanced secretion of mucosal IL-1 $\beta$ and TNF- $\alpha$, resulting in elevated T-cell and antibody responses, which were diminished in $\mathrm{NLRC4^{-/ }}$ mice [43]. Similarly, incorporating flagellin into the replicon of an alphavirus enhanced IgG1 and IgG2a/c titres, indicating an enhancement of Th1 and Th2 type responses. The adjuvanticity of the flagellin-expressing alphavirus was partially dependent on TLR5 [40]. In addition to virus-based delivery, flagellin has also been administered as a DNA-plasmid encoding the flagellin gene. After co-immunisation with a second OVA-encoding plasmid, mice showed Ag-specific antibody responses and MHC Class I-dependent cellular immune responses [42]. Of note, adjuvant delivery via DNA molecules might also activate the AIM2 inflammasome.

\subsection{AIM2 Inflammasome}

The AIM2 inflammasome is a sensor that detects intracellular DNA, which can originate from intracellular pathogens (PAMPs), or endogenous affected cells (DAMPs) that have lost nuclear envelope integrity [178]. Thus, it is not very surprising that AIM2 has been identified as a sensor of DNA vaccines, in which the Ag is produced in vivo by the endogenous transfected cells [46]. Here, the DNA plasmid itself represents an intrinsic adjuvant, which enhances immunogenicity towards the vaccine-encoded immunogens [46]. However, DNA vaccines have also been used in combination with established adjuvants such as Al-salts or CpG oligonucleotides [179]. Today, there are no DNA vaccines approved for use in humans but clinical trials using DNA vaccines against HIV and Hepatitis B have demonstrated potential immunogenicity [179]. DNA vaccine-induced humoral and cellular Ag-specific adaptive responses rely on the AIM2 inflammasome, but surprisingly not on IL-1R1 and IL-18R [46]. Interestingly, IFN- $\alpha / \beta$ were reduced in Aim2-deficient mice after DNA vaccination, which might indicate that DNA vaccines induce IFN- $\alpha / \beta$ signalling, thereby promoting dispensability of IL-1/IL-18 signalling [46]. Recently, two studies demonstrated that DNA vaccines encoding the Aim2 gene itself might be a promising approach to enhance immunogenicity [45,47].

\subsection{Pyrin Inflammasome}

The pyrin inflammasome senses inactivating modifications of the Rho GTPase (RhoA), which regulates cytoskeletal remodelling and is a frequently used pathogen entry route. Therefore, pyrin can indirectly sense so-called "homeostasis altering molecular processes" (HAMPs), which does not rely on the detection of conserved molecules and thus facilitates sensing of evolutionary novel infections $[180,181]$. Cholera toxin B (CTB) from Vibrio cholerae can be administered as a vaccine adjuvant in various forms such as Ag-fusion-protein, co-administered with an $\mathrm{Ag}$, chemically coupled to an $\mathrm{Ag}$, or as a DNA vaccine [182]. Cholera toxin has been shown to induce caspase-1 and IL-1R1-dependent Th17 responses in human monocytes, which upregulated expression of the inflammasome-related genes Nlrp1, Nlrp3, and Nlrc4 [48]. However, another study showed that NLRP3 activation differs between different strain biotypes of toxins secreted from Vibrio cholerae [50]. Recently, Orimo et al. showed that CTB induces IL- $1 \beta$ production in peritoneal macrophages through the NLRP3 and pyrin inflammasome [49]. Here, protein kinase A has been suggested to mediate RhoA phosphorylation in 
CTB-induced macrophages, which results in pyrin inflammasome-mediated IL-1 $\beta$ production [49]. Thus, the pyrin inflammasome may contribute to adjuvanticity of CTB.

\subsection{Non-Canonical Inflammasome}

The non-canonical inflammasome is represented by murine caspase- 11 and human caspase- $4 / 5$, which sense intracellular LPS [141,183]. Importantly, Zanoni et al. identified oxPAPC as a further ligand of caspase-11 [52]. oxPAPC "hyperactivates" living DCs via caspase-11, independent of TLR4 in an CD14-dependent manner, which results in non-canonical NLRP3 inflammasome activation $[52,53]$. In contrast to LPS, oxPAPC binds caspase- 11 via a different domain, which induces IL-1 $\beta / I L-18$ release but not pyroptosis. Of note, GSDMD is the regulator that mediates oxPAPC-induced IL-1 secretion from living cells [51]. It is currently unknown why GSDMD does not induce pyroptosis downstream of oxPAPC. The mechanism may involve active repair of GSDMD pores in living cells, but this remains to be tested [184]. This mechanism of hyperactivated APCs, which induces strong innate immune responses in absence of pyroptotic cell death might also activate adaptive immunity through long-lasting pro-inflammatory signalling. Indeed, using an OVA immunisation model, Zanoni et al. demonstrated that oxPAPC potentiates adaptive immune responses in a caspase-11-dependent manner [52]. Thus, oxPAPC is a promising candidate for future vaccine adjuvants, which may provide superior immunogenicity over conventional adjuvants such as $\mathrm{Al}$ salts, through hyperactivation and the lack of pyroptosis.

\section{Conclusions}

This review of the available literature highlights the complexities of evaluating and ascertaining the MoA of vaccine adjuvants. Adjuvants include a broad spectrum of compounds, often used in non-identical formulations between different laboratories, adding to the diversity of observations in their MoA. Frequently, in vivo experiments revealed substantial discrepancies in the observed MoA compared to previous in vitro analyses. Although in vitro studies are well suited to identifying adjuvant targets and generating hypotheses, we conclude that robust in vivo studies using clearly defined adjuvant formulations are indispensable for generating reliable data of adjuvant mechanisms of action. For in vivo studies, it is also important to include readouts of cell-based immunity, in addition to measurements of antibody production, as T-cells are the direct place of action for inflammasome-dependent cytokines. It must be noted however, that, although murine models represent an essential element in the pre-clinical development of novel vaccines, translatability to the clinic is often limited, due to the many differences on the physiological, cellular and molecular level between the species [185]. In this context it is of paramount importance to thoroughly evaluate safety profiles of new inflammasome activating adjuvants, since inappropriately strong inflammasome activation may induce IL-1 $\beta$ mediated inflammatory symptoms, as seen in auto-inflammatory diseases such as Familial Mediterranean fever or cryopyrin-associated periodic syndromes [186].

Depending on the specific adjuvant, inflammasomes can contribute to immunogenicity as an important bridge between innate and adaptive immunity. In particular, the NLRP3 inflammasome is involved in the MoA of established vaccine adjuvants, although the precise impact of NLRP3 activation on their adjuvanticity requires further evaluation. The combination of NLRP3-activating substances with various TLR agonists, which provide a robust priming signal through upregulation of pro-inflammatory genes, facilitate greatly enhanced innate immune responses and higher adaptive responses, resulting in robust and persistent protection from the addressed pathogen. Therefore, combinatorial NLPR3-activating vaccine adjuvants are a promising approach in advancing clinical vaccines. Other inflammasome such as NLRC4 also represent a promising target of vaccine adjuvants as they also induce caspase-1-mediated secretion of IL-1-family cytokines but require a more specific and tangible trigger with a potentially clearer MoA.

A drawback of inflammasome-activating adjuvants might be the induction of caspase-1-mediated pyroptosis, which although pro-inflammatory may also terminate immunostimulation as dying 
immune cells cannot provide persistent inflammatory signalling. Here, oxPAPC, an activator of the non-canonical inflammasome, may be capable of circumventing this issue as it induces the release of pro-inflammatory cytokines in absence of pyroptosis. Thus, oxPAPC-induced hyperactivation of APCs could be a promising concept for future vaccines.

In summary, inflammasomes have emerged as highly relevant mediators of the MoA of a number of vaccine adjuvants, and their engagement should be actively considered during "intelligent" vaccine design and the development and evaluation of novel immunostimulatory compounds for combating current and emerging pathogens.

Author Contributions: S.R., A.T., C.G., J.S.B. and A.M. have participated in the conceptualisation, writing, and editing of the manuscript; A.T. prepared the Figures. All authors have read and agreed to the published version of the manuscript.

Funding: We are grateful to the European Cooperation in Science and Technology (COST) Action CA16231 ENOVA (European Network of Vaccine Adjuvants) for supporting the publication of this manuscript.

Acknowledgments: We want to sincerely thank the authors of all cited publications for enhancing our knowledge of vaccine adjuvants, in particular in the context of inflammasome activation.

Conflicts of Interest: The authors declare no conflict of interest. The funders had no role in the writing of the manuscript.

\section{References}

1. Christensen, D. Vaccine adjuvants: Why and how. Hum. Vaccins Immunother. 2016, 12, 2709-2711. [CrossRef]

2. Di Pasquale, A.; Preiss, S.; Tavares Da Silva, F.; Garcon, N. Vaccine Adjuvants: From 1920 to 2015 and Beyond. Vaccines 2015, 3, 320-343. [CrossRef]

3. Reed, S.G.; Orr, M.T.; Fox, C.B. Key roles of adjuvants in modern vaccines. Nat. Med. 2013, 19, 1597-1608. [CrossRef]

4. Guy, B. The perfect mix: Recent progress in adjuvant research. Nat. Rev. Microbiol. 2007, 5, 505-517. [CrossRef]

5. Awate, S.; Babiuk, L.A.; Mutwiri, G. Mechanisms of action of adjuvants. Front. Immunol. 2013, 4, 114. [CrossRef]

6. Eisenbarth, S.C.; Colegio, O.R.; O'Connor, W.; Sutterwala, F.S.; Flavell, R.A. Crucial role for the Nalp3 inflammasome in the immunostimulatory properties of aluminium adjuvants. Nature 2008, 453, 1122-1126. [CrossRef]

7. Hornung, V.; Bauernfeind, F.; Halle, A.; Samstad, E.O.; Kono, H.; Rock, K.L.; Fitzgerald, K.A.; Latz, E. Silica crystals and aluminum salts activate the Nalp3 inflammasome through phagosomal destabilization. Nat. Immunol. 2008, 9, 847-856. [CrossRef]

8. Kool, M.; Petrilli, V.; De Smedt, T.; Rolaz, A.; Hammad, H.; van Nimwegen, M.; Bergen, I.M.; Castillo, R.; Lambrecht, B.N.; Tschopp, J. Cutting edge: Alum adjuvant stimulates inflammatory dendritic cells through activation of the NALP3 inflammasome. J. Immunol. 2008, 181, 3755-3759. [CrossRef]

9. Li, H.; Willingham, S.B.; Ting, J.P.; Re, F. Cutting edge: Inflammasome activation by alum and alum's adjuvant effect are mediated by NLRP3. J. Immunol. 2008, 181, 17-21. [CrossRef]

10. Neumann, S.; Burkert, K.; Kemp, R.; Rades, T.; Rod Dunbar, P.; Hook, S. Activation of the NLRP3 inflammasome is not a feature of all particulate vaccine adjuvants. Immunol. Cell Biol. 2014, 92, 535-542. [CrossRef]

11. Franchi, L.; Nunez, G. The Nlrp3 inflammasome is critical for aluminium hydroxide-mediated IL-1beta secretion but dispensable for adjuvant activity. Eur. J. Immunol. 2008, 38, 2085-2089. [CrossRef]

12. Marichal, T.; Ohata, K.; Bedoret, D.; Mesnil, C.; Sabatel, C.; Kobiyama, K.; Lekeux, P.; Coban, C.; Akira, S.; Ishii, K.J.; et al. DNA released from dying host cells mediates aluminum adjuvant activity. Nat. Med. 2011, 17, 996-1002. [CrossRef] 
13. McKee, A.S.; Munks, M.W.; MacLeod, M.K.; Fleenor, C.J.; Van Rooijen, N.; Kappler, J.W.; Marrack, P. Alum induces innate immune responses through macrophage and mast cell sensors, but these sensors are not required for alum to act as an adjuvant for specific immunity. J. Immunol. 2009, 183, 4403-4414. [CrossRef]

14. Quandt, D.; Rothe, K.; Baerwald, C.; Rossol, M. GPRC6A mediates Alum-induced Nlrp3 inflammasome activation but limits Th2 type antibody responses. Sci. Rep. 2015, 5, 16719. [CrossRef]

15. Seubert, A.; Calabro, S.; Santini, L.; Galli, B.; Genovese, A.; Valentini, S.; Aprea, S.; Colaprico, A.; D’Oro, U.; Giuliani, M.M.; et al. Adjuvanticity of the oil-in-water emulsion MF59 is independent of Nlrp3 inflammasome but requires the adaptor protein MyD88. Proc. Natl. Acad. Sci. USA 2011, 108, 11169-11174. [CrossRef]

16. Mosca, F.; Tritto, E.; Muzzi, A.; Monaci, E.; Bagnoli, F.; Iavarone, C.; O’Hagan, D.; Rappuoli, R.; De Gregorio, E. Molecular and cellular signatures of human vaccine adjuvants. Proc. Natl. Acad. Sci. USA 2008, 105, 10501-10506. [CrossRef]

17. Vono, M.; Taccone, M.; Caccin, P.; Gallotta, M.; Donvito, G.; Falzoni, S.; Palmieri, E.; Pallaoro, M.; Rappuoli, R.; Di Virgilio, F.; et al. The adjuvant MF59 induces ATP release from muscle that potentiates response to vaccination. Proc. Natl. Acad. Sci. USA 2013, 110, 21095-21100. [CrossRef]

18. Ellebedy, A.H.; Lupfer, C.; Ghoneim, H.E.; DeBeauchamp, J.; Kanneganti, T.D.; Webby, R.J. Inflammasome-independent role of the apoptosis-associated speck-like protein containing CARD (ASC) in the adjuvant effect of MF59. Proc. Natl. Acad. Sci. USA 2011, 108, 2927-2932. [CrossRef]

19. Detienne, S.; Welsby, I.; Collignon, C.; Wouters, S.; Coccia, M.; Delhaye, S.; Van Maele, L.; Thomas, S.; Swertvaegher, M.; Detavernier, A.; et al. Central Role of CD169(+) Lymph Node Resident Macrophages in the Adjuvanticity of the QS-21 Component of AS01. Sci. Rep. 2016, 6, 39475. [CrossRef]

20. Marty-Roix, R.; Vladimer, G.I.; Pouliot, K.; Weng, D.; Buglione-Corbett, R.; West, K.; MacMicking, J.D.; Chee, J.D.; Wang, S.; Lu, S.; et al. Identification of QS-21 as an Inflammasome-activating Molecular Component of Saponin Adjuvants. J. Biol. Chem. 2016, 291, 1123-1136. [CrossRef]

21. Welsby, I.; Detienne, S.; N'Kuli, F.; Thomas, S.; Wouters, S.; Bechtold, V.; De Wit, D.; Gineste, R.; Reinheckel, T.; Elouahabi, A.; et al. Lysosome-Dependent Activation of Human Dendritic Cells by the Vaccine Adjuvant QS-21. Front. Immunol. 2016, 7, 663. [CrossRef]

22. Giannini, S.L.; Hanon, E.; Moris, P.; Van Mechelen, M.; Morel, S.; Dessy, F.; Fourneau, M.A.; Colau, B.; Suzich, J.; Losonksy, G.; et al. Enhanced humoral and memory B cellular immunity using HPV16/18 L1 VLP vaccine formulated with the MPL/aluminium salt combination (AS04) compared to aluminium salt only. Vaccine 2006, 24, 5937-5949. [CrossRef]

23. Seydoux, E.; Liang, H.; Dubois Cauwelaert, N.; Archer, M.; Rintala, N.D.; Kramer, R.; Carter, D.; Fox, C.B.; Orr, M.T. Effective Combination Adjuvants Engage Both TLR and Inflammasome Pathways To Promote Potent Adaptive Immune Responses. J. Immunol. 2018, 201, 98-112. [CrossRef]

24. Duewell, P.; Kisser, U.; Heckelsmiller, K.; Hoves, S.; Stoitzner, P.; Koernig, S.; Morelli, A.B.; Clausen, B.E.; Dauer, M.; Eigler, A.; et al. ISCOMATRIX adjuvant combines immune activation with antigen delivery to dendritic cells in vivo leading to effective cross-priming of CD8+ T cells. J. Immunol. 2011, 187, 55-63. [CrossRef]

25. Wilson, N.S.; Duewell, P.; Yang, B.; Li, Y.; Marsters, S.; Koernig, S.; Latz, E.; Maraskovsky, E.; Morelli, A.B.; Schnurr, M.; et al. Inflammasome-dependent and -independent IL-18 production mediates immunity to the ISCOMATRIX adjuvant. J. Immunol. 2014, 192, 3259-3268. [CrossRef]

26. Kim, S.-K.; Park, K.-Y.; Choe, J.-Y. Toll-Like Receptor 9 Is Involved in NLRP3 Inflammasome Activation and IL-1 $\beta$ Production Through Monosodium Urate-Induced Mitochondrial DNA. Inflammation 2020, 43, 1-11. [CrossRef]

27. Hayashi, M.; Aoshi, T.; Kogai, Y.; Nomi, D.; Haseda, Y.; Kuroda, E.; Kobiyama, K.; Ishii, K.J. Optimization of physiological properties of hydroxyapatite as a vaccine adjuvant. Vaccine 2016, 34, 306-312. [CrossRef]

28. Pazar, B.; Ea, H.K.; Narayan, S.; Kolly, L.; Bagnoud, N.; Chobaz, V.; Roger, T.; Liote, F.; So, A.; Busso, N. Basic calcium phosphate crystals induce monocyte/macrophage IL-1beta secretion through the NLRP3 inflammasome in vitro. J. Immunol. 2011, 186, 2495-2502. [CrossRef]

29. Desel, C.; Werninghaus, K.; Ritter, M.; Jozefowski, K.; Wenzel, J.; Russkamp, N.; Schleicher, U.; Christensen, D.; Wirtz, S.; Kirschning, C.; et al. The Mincle-activating adjuvant TDB induces MyD88-dependent Th1 and Th17 responses through IL-1R signaling. PLoS ONE 2013, 8, e53531. [CrossRef] 
30. Schweneker, K.; Gorka, O.; Schweneker, M.; Poeck, H.; Tschopp, J.; Peschel, C.; Ruland, J.; Gross, O. The mycobacterial cord factor adjuvant analogue trehalose-6,6'-dibehenate (TDB) activates the Nlrp3 inflammasome. Immunobiology 2013, 218, 664-673. [CrossRef]

31. Sharp, F.A.; Ruane, D.; Claass, B.; Creagh, E.; Harris, J.; Malyala, P.; Singh, M.; O’Hagan, D.T.; Petrilli, V.; Tschopp, J.; et al. Uptake of particulate vaccine adjuvants by dendritic cells activates the NALP3 inflammasome. Proc. Natl. Acad. Sci. USA 2009, 106, 870-875. [CrossRef]

32. Zhu, Y.; Jiang, J.; Said-Sadier, N.; Boxx, G.; Champion, C.; Tetlow, A.; Kickhoefer, V.A.; Rome, L.H.; Ojcius, D.M.; Kelly, K.A. Activation of the NLRP3 inflammasome by vault nanoparticles expressing a chlamydial epitope. Vaccine 2015, 33, 298-306. [CrossRef]

33. Bueter, C.L.; Lee, C.K.; Wang, J.P.; Ostroff, G.R.; Specht, C.A.; Levitz, S.M. Spectrum and mechanisms of inflammasome activation by chitosan. J. Immunol. 2014, 192, 5943-5951. [CrossRef]

34. Carroll, E.C.; Jin, L.; Mori, A.; Munoz-Wolf, N.; Oleszycka, E.; Moran, H.B.T.; Mansouri, S.; McEntee, C.P.; Lambe, E.; Agger, E.M.; et al. The Vaccine Adjuvant Chitosan Promotes Cellular Immunity via DNA Sensor cGAS-STING-Dependent Induction of Type I Interferons. Immunity 2016, 44, 597-608. [CrossRef]

35. Lebre, F.; Pedroso de Lima, M.C.; Lavelle, E.C.; Borges, O. Mechanistic study of the adjuvant effect of chitosan-aluminum nanoparticles. Int. J. Pharm. 2018, 552, 7-15. [CrossRef]

36. Mori, A.; Oleszycka, E.; Sharp, F.A.; Coleman, M.; Ozasa, Y.; Singh, M.; O’Hagan, D.T.; Tajber, L.; Corrigan, O.I.; McNeela, E.A.; et al. The vaccine adjuvant alum inhibits IL-12 by promoting PI3 kinase signaling while chitosan does not inhibit IL-12 and enhances Th1 and Th17 responses. Eur. J. Immunol. 2012, 42, 2709-2719. [CrossRef]

37. Kusaka, T.; Nakayama, M.; Nakamura, K.; Ishimiya, M.; Furusawa, E.; Ogasawara, K. Effect of silica particle size on macrophage inflammatory responses. PLoS ONE 2014, 9, e92634. [CrossRef]

38. Peeters, P.M.; Perkins, T.N.; Wouters, E.F.; Mossman, B.T.; Reynaert, N.L. Silica induces NLRP3 inflammasome activation in human lung epithelial cells. Part. Fibre Toxicol. 2013, 10, 3. [CrossRef]

39. Niikura, K.; Matsunaga, T.; Suzuki, T.; Kobayashi, S.; Yamaguchi, H.; Orba, Y.; Kawaguchi, A.; Hasegawa, H.; Kajino, K.; Ninomiya, T.; et al. Gold nanoparticles as a vaccine platform: Influence of size and shape on immunological responses in vitro and in vivo. ACS Nano 2013, 7, 3926-3938. [CrossRef]

40. Knudsen, M.L.; Johansson, D.X.; Kostic, L.; Nordstrom, E.K.; Tegerstedt, K.; Pasetto, A.; Applequist, S.E.; Ljungberg, K.; Sirard, J.C.; Liljestrom, P. The adjuvant activity of alphavirus replicons is enhanced by incorporating the microbial molecule flagellin into the replicon. PLoS ONE 2013, 8, e65964. [CrossRef]

41. Lopez-Yglesias, A.H.; Zhao, X.; Quarles, E.K.; Lai, M.A.; VandenBos, T.; Strong, R.K.; Smith, K.D. Flagellin induces antibody responses through a TLR5- and inflammasome-independent pathway. J. Immunol. 2014, 192, 1587-1596. [CrossRef]

42. Nystrom, S.; Brave, A.; Falkeborn, T.; Devito, C.; Rissiek, B.; Johansson, D.X.; Schroder, U.; Uematsu, S.; Akira, S.; Hinkula, J.; et al. DNA-Encoded Flagellin Activates Toll-Like Receptor 5 (TLR5), Nod-like Receptor Family CARD Domain-Containing Protein 4 (NRLC4), and Acts as an Epidermal, Systemic, and Mucosal-Adjuvant. Vaccines 2013, 1, 415-443. [CrossRef]

43. Sanos, S.L.; Kassub, R.; Testori, M.; Geiger, M.; Patzold, J.; Giessel, R.; Knallinger, J.; Bathke, B.; Grabnitz, F.; Brinkmann, K.; et al. NLRC4 Inflammasome-Driven Immunogenicity of a Recombinant MVA Mucosal Vaccine Encoding Flagellin. Front. Immunol. 2017, 8, 1988. [CrossRef]

44. Vijay-Kumar, M.; Carvalho, F.A.; Aitken, J.D.; Fifadara, N.H.; Gewirtz, A.T. TLR5 or NLRC4 is necessary and sufficient for promotion of humoral immunity by flagellin. Eur. J. Immunol. 2010, 40, 3528-3534. [CrossRef]

45. Chai, D.; Shan, H.; Wang, G.; Zhang, Q.; Li, H.; Fang, L.; Song, J.; Liu, N.; Zhang, Q.; Yao, H.; et al. Combining DNA Vaccine and AIM2 in H1 Nanoparticles Exert Anti-Renal Carcinoma Effects via Enhancing Tumor-Specific Multi-functional CD8(+) T-cell Responses. Mol. Cancer Ther. 2019, 18, 323-334. [CrossRef]

46. Suschak, J.J.; Wang, S.; Fitzgerald, K.A.; Lu, S. Identification of Aim2 as a sensor for DNA vaccines. J. Immunol. 2015, 194, 630-636. [CrossRef]

47. Yin, L.; Chai, D.; Yue, Y.; Dong, C.; Xiong, S. AIM2 Co-immunization with VP1 Is Associated with Increased Memory CD8 T Cells and Mounts Long Lasting Protection against Coxsackievirus B3 Challenge. Front. Cell. Infect. Microbiol. 2017, 7, 247. [CrossRef]

48. Larena, M.; Holmgren, J.; Lebens, M.; Terrinoni, M.; Lundgren, A. Cholera toxin, and the related nontoxic adjuvants mmCT and dmLT, promote human Th17 responses via cyclic AMP-protein kinase A and inflammasome-dependent IL-1 signaling. J. Immunol. 2015, 194, 3829-3839. [CrossRef] 
49. Orimo, T.; Sasaki, I.; Hemmi, H.; Ozasa, T.; Fukuda-Ohta, Y.; Ohta, T.; Morinaka, M.; Kitauchi, M.; Yamaguchi, T.; Sato, Y.; et al. Cholera toxin B induces interleukin-1beta production from resident peritoneal macrophages through the pyrin inflammasome as well as the NLRP3 inflammasome. Int. Immunol. 2019, 31, 657-668. [CrossRef]

50. Queen, J.; Agarwal, S.; Dolores, J.S.; Stehlik, C.; Satchell, K.J. Mechanisms of inflammasome activation by Vibrio cholerae secreted toxins vary with strain biotype. Infect. Immun. 2015, 83, 2496-2506. [CrossRef]

51. Evavold, C.L.; Ruan, J.; Tan, Y.; Xia, S.; Wu, H.; Kagan, J.C. The Pore-Forming Protein Gasdermin D Regulates Interleukin-1 Secretion from Living Macrophages. Immunity 2018, 48, 35-44.e36. [CrossRef]

52. Zanoni, I.; Tan, Y.; Di Gioia, M.; Broggi, A.; Ruan, J.; Shi, J.; Donado, C.A.; Shao, F.; Wu, H.; Springstead, J.R.; et al. An endogenous caspase-11 ligand elicits interleukin-1 release from living dendritic cells. Science 2016, 352, 1232-1236. [CrossRef]

53. Zanoni, I.; Tan, Y.; Di Gioia, M.; Springstead, J.R.; Kagan, J.C. By Capturing Inflammatory Lipids Released from Dying Cells, the Receptor CD14 Induces Inflammasome-Dependent Phagocyte Hyperactivation. Immunity 2017, 47, 697-709.e693. [CrossRef]

54. Martinon, F.; Burns, K.; Tschopp, J. The inflammasome: A molecular platform triggering activation of inflammatory caspases and processing of proIL-beta. Mol. Cell 2002, 10, 417-426. [CrossRef]

55. Broz, P.; Dixit, V.M. Inflammasomes: Mechanism of assembly, regulation and signalling. Nat. Rev. Immunol. 2016, 16, 407-420. [CrossRef]

56. Muñoz-Wolf, N.; McCluskey, S.; Lavelle, E.C. The Role of Inflammasomes in Adjuvant-Driven Humoral and Cellular Immune Responses. In Immunopotentiators in Modern Vaccines, 2nd ed.; Schijns, V.E.J.C., O’Hagan, D.T., Eds.; Academic Press: Cambridge, MA, USA, 2017; pp. $23-42$.

57. Bauernfeind, F.G.; Horvath, G.; Stutz, A.; Alnemri, E.S.; MacDonald, K.; Speert, D.; Fernandes-Alnemri, T.; $\mathrm{Wu}$, J.; Monks, B.G.; Fitzgerald, K.A.; et al. Cutting edge: NF-kappaB activating pattern recognition and cytokine receptors license NLRP3 inflammasome activation by regulating NLRP3 expression. J. Immunol. 2009, 183, 787-791. [CrossRef]

58. Sharma, D.; Kanneganti, T.D. The cell biology of inflammasomes: Mechanisms of inflammasome activation and regulation. J. Cell Biol. 2016, 213, 617-629. [CrossRef]

59. Platnich, J.M.; Muruve, D.A. NOD-like receptors and inflammasomes: A review of their canonical and non-canonical signaling pathways. Arch. Biochem. Biophys. 2019, 670, 4-14. [CrossRef]

60. Chen, J.; Chen, Z.J. PtdIns4P on dispersed trans-Golgi network mediates NLRP3 inflammasome activation. Nature 2018, 564, 71-76. [CrossRef]

61. Munoz-Planillo, R.; Kuffa, P.; Martinez-Colon, G.; Smith, B.L.; Rajendiran, T.M.; Nunez, G. K(+) efflux is the common trigger of NLRP3 inflammasome activation by bacterial toxins and particulate matter. Immunity 2013, 38, 1142-1153. [CrossRef]

62. Cui, B.; Liu, X.; Fang, Y.; Zhou, P.; Zhang, Y.; Wang, Y. Flagellin as a vaccine adjuvant. Expert Rev. Vaccines 2018, 17, 335-349. [CrossRef]

63. Rathinam, V.A.K.; Zhao, Y.; Shao, F. Innate immunity to intracellular LPS. Nat. Immunol. 2019, 20, 527-533. [CrossRef]

64. Evavold, C.L.; Kagan, J.C. How Inflammasomes Inform Adaptive Immunity. J. Mol. Biol. 2018, 430, $217-237$. [CrossRef]

65. Banchereau, J.; Steinman, R.M. Dendritic cells and the control of immunity. Nature 1998, 392, $245-252$. [CrossRef]

66. Iwasaki, A.; Medzhitov, R. Control of adaptive immunity by the innate immune system. Nat. Immunol. 2015, 16, 343-353. [CrossRef]

67. Caux, C.; Massacrier, C.; Vanbervliet, B.; Dubois, B.; Van Kooten, C.; Durand, I.; Banchereau, J. Activation of human dendritic cells through CD40 cross-linking. J. Exp. Med. 1994, 180, 1263-1272. [CrossRef]

68. Cella, M.; Engering, A.; Pinet, V.; Pieters, J.; Lanzavecchia, A. Inflammatory stimuli induce accumulation of MHC class II complexes on dendritic cells. Nature 1997, 388, 782-787. [CrossRef]

69. Pierre, P.; Turley, S.J.; Gatti, E.; Hull, M.; Meltzer, J.; Mirza, A.; Inaba, K.; Steinman, R.M.; Mellman, I. Developmental regulation of MHC class II transport in mouse dendritic cells. Nature 1997, 388, 787-792. [CrossRef] 
70. Reis e Sousa, C.; Hieny, S.; Scharton-Kersten, T.; Jankovic, D.; Charest, H.; Germain, R.N.; Sher, A. In vivo microbial stimulation induces rapid CD40 ligand-independent production of interleukin 12 by dendritic cells and their redistribution to T cell areas. J. Exp. Med. 1997, 186, 1819-1829. [CrossRef]

71. Monteleone, M.; Stanley, A.C.; Chen, K.W.; Brown, D.L.; Bezbradica, J.S.; von Pein, J.B.; Holley, C.L.; Boucher, D.; Shakespear, M.R.; Kapetanovic, R.; et al. Interleukin-1beta Maturation Triggers Its Relocation to the Plasma Membrane for Gasdermin-D-Dependent and -Independent Secretion. Cell Rep. 2018, 24, 1425-1433. [CrossRef]

72. Munoz-Wolf, N.; Lavelle, E.C. A Guide to IL-1 family cytokines in adjuvanticity. FEBS J. 2018, 285, $2377-2401$. [CrossRef] [PubMed]

73. Garlanda, C.; Dinarello, C.A.; Mantovani, A. The interleukin-1 family: Back to the future. Immunity 2013, 39, 1003-1018. [CrossRef] [PubMed]

74. Acosta-Rodriguez, E.V.; Napolitani, G.; Lanzavecchia, A.; Sallusto, F. Interleukins 1beta and 6 but not transforming growth factor-beta are essential for the differentiation of interleukin 17-producing human $\mathrm{T}$ helper cells. Nat. Immunol. 2007, 8, 942-949. [CrossRef]

75. Ben-Sasson, S.Z.; Hogg, A.; Hu-Li, J.; Wingfield, P.; Chen, X.; Crank, M.; Caucheteux, S.; Ratner-Hurevich, M.; Berzofsky, J.A.; Nir-Paz, R.; et al. IL-1 enhances expansion, effector function, tissue localization, and memory response of antigen-specific CD8 T cells. J. Exp. Med. 2013, 210, 491-502. [CrossRef] [PubMed]

76. Ben-Sasson, S.Z.; Hu-Li, J.; Quiel, J.; Cauchetaux, S.; Ratner, M.; Shapira, I.; Dinarello, C.A.; Paul, W.E. IL-1 acts directly on CD4 T cells to enhance their antigen-driven expansion and differentiation. Proc. Natl. Acad. Sci. USA 2009, 106, 7119-7124. [CrossRef] [PubMed]

77. Kryczek, I.; Wei, S.; Vatan, L.; Escara-Wilke, J.; Szeliga, W.; Keller, E.T.; Zou, W. Cutting edge: Opposite effects of IL-1 and IL-2 on the regulation of IL-17+ T cell pool IL-1 subverts IL-2-mediated suppression. J. Immunol. 2007, 179, 1423-1426. [CrossRef]

78. O'Sullivan, B.J.; Thomas, H.E.; Pai, S.; Santamaria, P.; Iwakura, Y.; Steptoe, R.J.; Kay, T.W.; Thomas, R. IL-1 beta breaks tolerance through expansion of CD25+ effector T cells. J. Immunol. 2006, 176, 7278-7287. [CrossRef]

79. Plaetinck, G.; Combe, M.C.; Corthesy, P.; Sperisen, P.; Kanamori, H.; Honjo, T.; Nabholz, M. Control of IL-2 receptor-alpha expression by IL-1, tumor necrosis factor, and IL-2. Complex regulation via elements in the $5^{\prime}$ flanking region. J. Immunol. 1990, 145, 3340-3347.

80. Veldhoen, M.; Hocking, R.J.; Atkins, C.J.; Locksley, R.M.; Stockinger, B. TGFbeta in the context of an inflammatory cytokine milieu supports de novo differentiation of IL-17-producing T cells. Immunity 2006, 24, 179-189. [CrossRef]

81. Von Rossum, A.; Krall, R.; Escalante, N.K.; Choy, J.C. Inflammatory cytokines determine the susceptibility of human CD8 T cells to Fas-mediated activation-induced cell death through modulation of FasL and c-FLIP(S) expression. J. Biol. Chem. 2011, 286, 21137-21144. [CrossRef]

82. Wilson, N.J.; Boniface, K.; Chan, J.R.; McKenzie, B.S.; Blumenschein, W.M.; Mattson, J.D.; Basham, B.; Smith, K.; Chen, T.; Morel, F.; et al. Development, cytokine profile and function of human interleukin 17-producing helper T cells. Nat. Immunol. 2007, 8, 950-957. [CrossRef] [PubMed]

83. Revu, S.; Wu, J.; Henkel, M.; Rittenhouse, N.; Menk, A.; Delgoffe, G.M.; Poholek, A.C.; McGeachy, M.J. IL-23 and IL-1beta Drive Human Th17 Cell Differentiation and Metabolic Reprogramming in Absence of CD28 Costimulation. Cell Rep. 2018, 22, 2642-2653. [CrossRef] [PubMed]

84. Sallusto, F.; Zielinski, C.E.; Lanzavecchia, A. Human Th17 subsets. Eur. J. Immunol. 2012, 42, $2215-2220$. [CrossRef] [PubMed]

85. Ahn, H.J.; Maruo, S.; Tomura, M.; Mu, J.; Hamaoka, T.; Nakanishi, K.; Clark, S.; Kurimoto, M.; Okamura, H.; Fujiwara, H. A mechanism underlying synergy between IL-12 and IFN-gamma-inducing factor in enhanced production of IFN-gamma. J. Immunol. 1997, 159, 2125-2131. [PubMed]

86. Bernink, J.H.; Krabbendam, L.; Germar, K.; de Jong, E.; Gronke, K.; Kofoed-Nielsen, M.; Munneke, J.M.; Hazenberg, M.D.; Villaudy, J.; Buskens, C.J.; et al. Interleukin-12 and -23 Control Plasticity of CD127(+) Group 1 and Group 3 Innate Lymphoid Cells in the Intestinal Lamina Propria. Immunity 2015, 43, 146-160. [CrossRef]

87. Blom, L.; Poulsen, L.K. IL-1 family members IL-18 and IL-33 upregulate the inflammatory potential of differentiated human Th1 and Th2 cultures. J. Immunol. 2012, 189, 4331-4337. [CrossRef] 
88. Chaix, J.; Tessmer, M.S.; Hoebe, K.; Fuseri, N.; Ryffel, B.; Dalod, M.; Alexopoulou, L.; Beutler, B.; Brossay, L.; Vivier, E.; et al. Cutting edge: Priming of NK cells by IL-18. J. Immunol. 2008, 181, 1627-1631. [CrossRef]

89. Chang, J.T.; Segal, B.M.; Nakanishi, K.; Okamura, H.; Shevach, E.M. The costimulatory effect of IL-18 on the induction of antigen-specific IFN-gamma production by resting T cells is IL-12 dependent and is mediated by up-regulation of the IL-12 receptor beta2 subunit. Eur. J. Immunol. 2000, 30, 1113-1119. [CrossRef]

90. Guo, L.; Wei, G.; Zhu, J.; Liao, W.; Leonard, W.J.; Zhao, K.; Paul, W. IL-1 family members and STAT activators induce cytokine production by Th2, Th17, and Th1 cells. Proc. Natl. Acad. Sci. USA 2009, 106, 13463-13468. [CrossRef]

91. Okamura, H.; Tsutsi, H.; Komatsu, T.; Yutsudo, M.; Hakura, A.; Tanimoto, T.; Torigoe, K.; Okura, T.; Nukada, Y.; Hattori, K.; et al. Cloning of a new cytokine that induces IFN-gamma production by T cells. Nature 1995, 378, 88-91. [CrossRef]

92. Xu, D.; Chan, W.L.; Leung, B.P.; Hunter, D.; Schulz, K.; Carter, R.W.; McInnes, I.B.; Robinson, J.H.; Liew, F.Y. Selective expression and functions of interleukin 18 receptor on Thelper (Th) type 1 but not Th2 cells. J. Exp. Med. 1998, 188, 1485-1492. [CrossRef] [PubMed]

93. Yoshimoto, T.; Takeda, K.; Tanaka, T.; Ohkusu, K.; Kashiwamura, S.; Okamura, H.; Akira, S.; Nakanishi, K. IL-12 up-regulates IL-18 receptor expression on T cells, Th1 cells, and B cells: Synergism with IL-18 for IFN-gamma production. J. Immunol. 1998, 161, 3400-3407. [PubMed]

94. Desbien, A.L.; Reed, S.J.; Bailor, H.R.; Dubois Cauwelaert, N.; Laurance, J.D.; Orr, M.T.; Fox, C.B.; Carter, D.; Reed, S.G.; Duthie, M.S. Squalene emulsion potentiates the adjuvant activity of the TLR4 agonist, GLA, via inflammatory caspases, IL-18, and IFN-gamma. Eur. J. Immunol. 2015, 45, 407-417. [CrossRef] [PubMed]

95. Xu, D.; Trajkovic, V.; Hunter, D.; Leung, B.P.; Schulz, K.; Gracie, J.A.; McInnes, I.B.; Liew, F.Y. IL-18 induces the differentiation of Th1 or Th2 cells depending upon cytokine milieu and genetic background. Eur. J. Immunol. 2000, 30, 3147-3156. [CrossRef]

96. Bonilla, W.V.; Frohlich, A.; Senn, K.; Kallert, S.; Fernandez, M.; Johnson, S.; Kreutzfeldt, M.; Hegazy, A.N.; Schrick, C.; Fallon, P.G.; et al. The alarmin interleukin-33 drives protective antiviral CD8(+) T cell responses. Science 2012, 335, 984-989. [CrossRef]

97. Komai-Koma, M.; Gilchrist, D.S.; McKenzie, A.N.; Goodyear, C.S.; Xu, D.; Liew, F.Y. IL-33 activates B1 cells and exacerbates contact sensitivity. J. Immunol. 2011, 186, 2584-2591. [CrossRef]

98. Stier, M.T.; Mitra, R.; Nyhoff, L.E.; Goleniewska, K.; Zhang, J.; Puccetti, M.V.; Casanova, H.C.; Seegmiller, A.C.; Newcomb, D.C.; Kendall, P.L.; et al. IL-33 Is a Cell-Intrinsic Regulator of Fitness during Early B Cell Development. J. Immunol. 2019, 203, 1457-1467. [CrossRef]

99. Li, S.; Neff, C.P.; Barber, K.; Hong, J.; Luo, Y.; Azam, T.; Palmer, B.E.; Fujita, M.; Garlanda, C.; Mantovani, A.; et al. Extracellular forms of IL-37 inhibit innate inflammation in vitro and in vivo but require the IL-1 family decoy receptor IL-1R8. Proc. Natl. Acad. Sci. USA 2015, 112, 2497-2502. [CrossRef]

100. Nold-Petry, C.A.; Lo, C.Y.; Rudloff, I.; Elgass, K.D.; Li, S.; Gantier, M.P.; Lotz-Havla, A.S.; Gersting, S.W.; Cho, S.X.; Lao, J.C.; et al. IL-37 requires the receptors IL-18Ralpha and IL-1R8 (SIGIRR) to carry out its multifaceted anti-inflammatory program upon innate signal transduction. Nat. Immunol. 2015, 16, 354-365. [CrossRef]

101. Nold, M.F.; Nold-Petry, C.A.; Zepp, J.A.; Palmer, B.E.; Bufler, P.; Dinarello, C.A. IL-37 is a fundamental inhibitor of innate immunity. Nat. Immunol. 2010, 11, 1014-1022. [CrossRef]

102. Winkler, S.; Rosen-Wolff, A. Caspase-1: An integral regulator of innate immunity. Semin. Immunopathol. 2015, 37, 419-427. [CrossRef] [PubMed]

103. Del Giudice, G.; Rappuoli, R.; Didierlaurent, A.M. Correlates of adjuvanticity: A review on adjuvants in licensed vaccines. Semin. Immunol. 2018, 39, 14-21. [CrossRef] [PubMed]

104. Brito, L.A.; Malyala, P.; O'Hagan, D.T. Vaccine adjuvant formulations: A pharmaceutical perspective. Semin. Immunol. 2013, 25, 130-145. [CrossRef] [PubMed]

105. Cain, D.W.; Sanders, S.E.; Cunningham, M.M.; Kelsoe, G. Disparate adjuvant properties among three formulations of "alum". Vaccine 2013, 31, 653-660. [CrossRef] [PubMed]

106. Flach, T.L.; Ng, G.; Hari, A.; Desrosiers, M.D.; Zhang, P.; Ward, S.M.; Seamone, M.E.; Vilaysane, A.; Mucsi, A.D.; Fong, Y.; et al. Alum interaction with dendritic cell membrane lipids is essential for its adjuvanticity. Nat. Med. 2011, 17, 479-487. [CrossRef] [PubMed] 
107. Ng, G.; Sharma, K.; Ward, S.M.; Desrosiers, M.D.; Stephens, L.A.; Schoel, W.M.; Li, T.; Lowell, C.A.; Ling, C.C.; Amrein, M.W.; et al. Receptor-independent, direct membrane binding leads to cell-surface lipid sorting and Syk kinase activation in dendritic cells. Immunity 2008, 29, 807-818. [CrossRef]

108. Prochnicki, T.; Latz, E. Inflammasomes on the Crossroads of Innate Immune Recognition and Metabolic Control. Cell Metab. 2017, 26, 71-93. [CrossRef]

109. Chioato, A.; Noseda, E.; Felix, S.D.; Stevens, M.; Del Giudice, G.; Fitoussi, S.; Kleinschmidt, A. Influenza and meningococcal vaccinations are effective in healthy subjects treated with the interleukin-1 beta-blocking antibody canakinumab: Results of an open-label, parallel group, randomized, single-center study. Clin. Vaccine Immunol. 2010, 17, 1952-1957. [CrossRef]

110. Nadel, S.; Ninis, N. Invasive Meningococcal Disease in the Vaccine Era. Front. Pediatr. 2018, 6, 321. [CrossRef]

111. Sun, B.; Ji, Z.; Liao, Y.P.; Chang, C.H.; Wang, X.; Ku, J.; Xue, C.; Mirshafiee, V.; Xia, T. Enhanced Immune Adjuvant Activity of Aluminum Oxyhydroxide Nanorods through Cationic Surface Functionalization. ACS Appl. Mater. Interfaces 2017, 9, 21697-21705. [CrossRef]

112. Thakkar, S.G.; Xu, H.; Li, X.; Cui, Z. Uric acid and the vaccine adjuvant activity of aluminium (oxy)hydroxide nanoparticles. J. Drug Target. 2018, 26, 474-480. [CrossRef] [PubMed]

113. Orr, M.T.; Khandhar, A.P.; Seydoux, E.; Liang, H.; Gage, E.; Mikasa, T.; Beebe, E.L.; Rintala, N.D.; Persson, K.H.; Ahniyaz, A.; et al. Reprogramming the adjuvant properties of aluminum oxyhydroxide with nanoparticle technology. NPJ Vaccines 2019, 4, 1. [CrossRef] [PubMed]

114. Bonam, S.R.; Partidos, C.D.; Halmuthur, S.K.M.; Muller, S. An Overview of Novel Adjuvants Designed for Improving Vaccine Efficacy. Trends Pharmacol. Sci. 2017, 38, 771-793. [CrossRef] [PubMed]

115. Didierlaurent, A.M.; Morel, S.; Lockman, L.; Giannini, S.L.; Bisteau, M.; Carlsen, H.; Kielland, A.; Vosters, O.; Vanderheyde, N.; Schiavetti, F.; et al. AS04, an aluminum salt- and TLR4 agonist-based adjuvant system, induces a transient localized innate immune response leading to enhanced adaptive immunity. J. Immunol. 2009, 183, 6186-6197. [CrossRef]

116. Leroux-Roels, G.; Marchant, A.; Levy, J.; Van Damme, P.; Schwarz, T.F.; Horsmans, Y.; Jilg, W.; Kremsner, P.G.; Haelterman, E.; Clement, F.; et al. Impact of adjuvants on CD4(+) T cell and B cell responses to a protein antigen vaccine: Results from a phase II, randomized, multicenter trial. Clin. Immunol. 2016, 169, $16-27$. [CrossRef]

117. Richou, R.; Jensen, R.; Belin, C. Research on Saponin, an Adjuvant Substance Which Stimulates Immunity. I. Rev. Immunol. Ther. Antimicrob. 1964, 28, 49-62.

118. Den Brok, M.H.; Bull, C.; Wassink, M.; de Graaf, A.M.; Wagenaars, J.A.; Minderman, M.; Thakur, M.; Amigorena, S.; Rijke, E.O.; Schrier, C.C.; et al. Saponin-based adjuvants induce cross-presentation in dendritic cells by intracellular lipid body formation. Nat. Commun. 2016, 7, 13324. [CrossRef]

119. Garcon, N.; Di Pasquale, A. From discovery to licensure, the Adjuvant System story. Hum. Vaccines Immunother. 2017, 13, 19-33. [CrossRef]

120. Baker, P.J.; Boucher, D.; Bierschenk, D.; Tebartz, C.; Whitney, P.G.; D'Silva, D.B.; Tanzer, M.C.; Monteleone, M.; Robertson, A.A.; Cooper, M.A.; et al. NLRP3 inflammasome activation downstream of cytoplasmic LPS recognition by both caspase-4 and caspase-5. Eur. J. Immunol. 2015, 45, 2918-2926. [CrossRef]

121. Ruhl, S.; Broz, P. Caspase-11 activates a canonical NLRP3 inflammasome by promoting $\mathrm{K}(+)$ efflux. Eur. J. Immunol. 2015, 45, 2927-2936. [CrossRef]

122. Schmid-Burgk, J.L.; Gaidt, M.M.; Schmidt, T.; Ebert, T.S.; Bartok, E.; Hornung, V. Caspase-4 mediates non-canonical activation of the NLRP3 inflammasome in human myeloid cells. Eur. J. Immunol. 2015, 45, 2911-2917. [CrossRef]

123. Coccia, M.; Collignon, C.; Herve, C.; Chalon, A.; Welsby, I.; Detienne, S.; van Helden, M.J.; Dutta, S.; Genito, C.J.; Waters, N.C.; et al. Cellular and molecular synergy in AS01-adjuvanted vaccines results in an early IFNgamma response promoting vaccine immunogenicity. NPJ Vaccines 2017, 2, 25. [CrossRef] [PubMed]

124. Lacaille-Dubois, M.A. Updated insights into the mechanism of action and clinical profile of the immunoadjuvant QS-21: A review. Phytomedicine 2019, 60, 152905. [CrossRef]

125. Moris, P.; Jongert, E.; van der Most, R.G. Characterization of T-cell immune responses in clinical trials of the candidate RTS,S malaria vaccine. Hum. Vaccines Immunother. 2018, 14, 17-27. [CrossRef] [PubMed] 
126. Morein, B.; Sundquist, B.; Hoglund, S.; Dalsgaard, K.; Osterhaus, A. Iscom, a novel structure for antigenic presentation of membrane proteins from enveloped viruses. Nature 1984, 308, 457-460. [CrossRef] [PubMed]

127. Bigaeva, E.; Doorn, E.; Liu, H.; Hak, E. Meta-Analysis on Randomized Controlled Trials of Vaccines with QS-21 or ISCOMATRIX Adjuvant: Safety and Tolerability. PLoS ONE 2016, 11, e0154757. [CrossRef]

128. Cibulski, S.P.; Rivera-Patron, M.; Mourglia-Ettlin, G.; Casaravilla, C.; Yendo, A.C.A.; Fett-Neto, A.G.; Chabalgoity, J.A.; Moreno, M.; Roehe, P.M.; Silveira, F. Quillaja brasiliensis saponin-based nanoparticulate adjuvants are capable of triggering early immune responses. Sci. Rep. 2018, 8, 13582. [CrossRef]

129. Sun, H.X.; Wang, H.; Xu, H.S.; Ni, Y. Novel polysaccharide adjuvant from the roots of Actinidia eriantha with dual Th1 and Th2 potentiating activity. Vaccine 2009, 27, 3984-3991. [CrossRef]

130. Bossaller, L.; Chiang, P.I.; Schmidt-Lauber, C.; Ganesan, S.; Kaiser, W.J.; Rathinam, V.A.; Mocarski, E.S.; Subramanian, D.; Green, D.R.; Silverman, N.; et al. Cutting edge: FAS (CD95) mediates noncanonical IL-1beta and IL-18 maturation via caspase-8 in an RIP3-independent manner. J. Immunol. 2012, 189, 5508-5512. [CrossRef]

131. Cibulski, S.P.; Mourglia-Ettlin, G.; Teixeira, T.F.; Quirici, L.; Roehe, P.M.; Ferreira, F.; Silveira, F. Novel ISCOMs from Quillaja brasiliensis saponins induce mucosal and systemic antibody production, T-cell responses and improved antigen uptake. Vaccine 2016, 34, 1162-1171. [CrossRef]

132. Aucouturier, J.; Dupuis, L.; Deville, S.; Ascarateil, S.; Ganne, V. Montanide ISA 720 and 51: A new generation of water in oil emulsions as adjuvants for human vaccines. Expert Rev. Vaccines 2002, 1, 111-118. [CrossRef] [PubMed]

133. Podda, A.; Del Giudice, G. MF59-adjuvanted vaccines: Increased immunogenicity with an optimal safety profile. Expert Rev. Vaccines 2003, 2, 197-203. [CrossRef] [PubMed]

134. Aucouturier, J.; Dupuis, L.; Ganne, V. Adjuvants designed for veterinary and human vaccines. Vaccine 2001, 19, 2666-2672. [CrossRef]

135. Benichou, A.; Aserin, A.; Garti, N. O/W/O double emulsions stabilized with WPI-polysaccharide conjugates. Colloids Surf. A Physicochem. Eng. Asp. 2007, 297, 211-220. [CrossRef]

136. Del Giudice, G.; Rappuoli, R. Inactivated and adjuvanted influenza vaccines. Curr. Top. Microbiol. Immunol. 2015, 386, 151-180. [CrossRef] [PubMed]

137. Garcon, N.; Vaughn, D.W.; Didierlaurent, A.M. Development and evaluation of AS03, an Adjuvant System containing alpha-tocopherol and squalene in an oil-in-water emulsion. Expert Rev. Vaccines 2012, 11, 349-366. [CrossRef]

138. Wilkins, A.L.; Kazmin, D.; Napolitani, G.; Clutterbuck, E.A.; Pulendran, B.; Siegrist, C.A.; Pollard, A.J. AS03and MF59-Adjuvanted Influenza Vaccines in Children. Front. Immunol. 2017, 8, 1760. [CrossRef]

139. Calabro, S.; Tritto, E.; Pezzotti, A.; Taccone, M.; Muzzi, A.; Bertholet, S.; De Gregorio, E.; O’Hagan, D.T.; Baudner, B.; Seubert, A. The adjuvant effect of MF59 is due to the oil-in-water emulsion formulation, none of the individual components induce a comparable adjuvant effect. Vaccine 2013, 31, 3363-3369. [CrossRef]

140. Morel, S.; Didierlaurent, A.; Bourguignon, P.; Delhaye, S.; Baras, B.; Jacob, V.; Planty, C.; Elouahabi, A.; Harvengt, P.; Carlsen, H.; et al. Adjuvant System AS03 containing alpha-tocopherol modulates innate immune response and leads to improved adaptive immunity. Vaccine 2011, 29, 2461-2473. [CrossRef]

141. Kayagaki, N.; Warming, S.; Lamkanfi, M.; Vande Walle, L.; Louie, S.; Dong, J.; Newton, K.; Qu, Y.; Liu, J.; Heldens, S.; et al. Non-canonical inflammasome activation targets caspase-11. Nature 2011, 479, 117-121. [CrossRef]

142. Okemoto, K.; Kawasaki, K.; Hanada, K.; Miura, M.; Nishijima, M. A potent adjuvant monophosphoryl lipid A triggers various immune responses, but not secretion of IL-1beta or activation of caspase-1. J. Immunol. 2006, 176, 1203-1208. [CrossRef] [PubMed]

143. Latz, E.; Xiao, T.S.; Stutz, A. Activation and regulation of the inflammasomes. Nat. Rev. Immunol. 2013, 13, 397-411. [CrossRef] [PubMed]

144. Reinke, S.; Linge, M.; Diebner, H.H.; Luksch, H.; Glage, S.; Gocht, A.; Robertson, A.A.B.; Cooper, M.A.; Hofmann, S.R.; Naumann, R.; et al. Non-canonical Caspase-1 Signaling Drives RIP2-Dependent and TNF-alpha-Mediated Inflammation In Vivo. Cell Rep. 2020, 30, 2501-2511.e2505. [CrossRef] [PubMed]

145. Mata-Haro, V.; Cekic, C.; Martin, M.; Chilton, P.M.; Casella, C.R.; Mitchell, T.C. The vaccine adjuvant monophosphoryl lipid A as a TRIF-biased agonist of TLR4. Science 2007, 316, 1628-1632. [CrossRef]

146. Martins, K.A.; Bavari, S.; Salazar, A.M. Vaccine adjuvant uses of poly-IC and derivatives. Expert Rev. Vaccines 2015, 14, 447-459. [CrossRef] [PubMed] 
147. Vasilakos, J.P.; Tomai, M.A. The use of Toll-like receptor $7 / 8$ agonists as vaccine adjuvants. Expert Rev. Vaccines 2013, 12, 809-819. [CrossRef]

148. Sablan, B.P.; Kim, D.J.; Barzaga, N.G.; Chow, W.C.; Cho, M.; Ahn, S.H.; Hwang, S.G.; Lee, J.H.; Namini, H.; Heyward, W.L. Demonstration of safety and enhanced seroprotection against hepatitis B with investigational HBsAg-1018 ISS vaccine compared to a licensed hepatitis B vaccine. Vaccine 2012, 30, 2689-2696. [CrossRef]

149. Scheiermann, J.; Klinman, D.M. Clinical evaluation of $\mathrm{CpG}$ oligonucleotides as adjuvants for vaccines targeting infectious diseases and cancer. Vaccine 2014, 32, 6377-6389. [CrossRef]

150. Hopkins, R.J.; Daczkowski, N.F.; Kaptur, P.E.; Muse, D.; Sheldon, E.; LaForce, C.; Sari, S.; Rudge, T.L.; Bernton, E. Randomized, double-blind, placebo-controlled, safety and immunogenicity study of 4 formulations of Anthrax Vaccine Adsorbed plus CPG 7909 (AV7909) in healthy adult volunteers. Vaccine 2013, 31, 3051-3058. [CrossRef]

151. Rynkiewicz, D.; Rathkopf, M.; Sim, I.; Waytes, A.T.; Hopkins, R.J.; Giri, L.; DeMuria, D.; Ransom, J.; Quinn, J.; Nabors, G.S.; et al. Marked enhancement of the immune response to BioThrax(R) (Anthrax Vaccine Adsorbed) by the TLR9 agonist CPG 7909 in healthy volunteers. Vaccine 2011, 29, 6313-6320. [CrossRef]

152. Halperin, S.A.; Van Nest, G.; Smith, B.; Abtahi, S.; Whiley, H.; Eiden, J.J. A phase I study of the safety and immunogenicity of recombinant hepatitis B surface antigen co-administered with an immunostimulatory phosphorothioate oligonucleotide adjuvant. Vaccine 2003, 21, 2461-2467. [CrossRef]

153. Angel, J.B.; Cooper, C.L.; Clinch, J.; Young, C.D.; Chenier, A.; Parato, K.G.; Lautru, M.; Davis, H.; Cameron, D.W. CPG increases vaccine antigen-specific cell-mediated immunity when administered with hepatitis $B$ vaccine in HIV infection. J. Immune Based Ther. Vaccines 2008, 6, 4. [CrossRef] [PubMed]

154. Cooper, C.L.; Davis, H.L.; Angel, J.B.; Morris, M.L.; Elfer, S.M.; Seguin, I.; Krieg, A.M.; Cameron, D.W. CPG 7909 adjuvant improves hepatitis B virus vaccine seroprotection in antiretroviral-treated HIV-infected adults. AIDS 2005, 19, 1473-1479. [CrossRef] [PubMed]

155. Li, P.; Wang, F. Polysaccharides: Candidates of promising vaccine adjuvants. Drug Discov. Ther. 2015, 9, 88-93. [CrossRef] [PubMed]

156. Davidsen, J.; Rosenkrands, I.; Christensen, D.; Vangala, A.; Kirby, D.; Perrie, Y.; Agger, E.M.; Andersen, P. Characterization of cationic liposomes based on dimethyldioctadecylammonium and synthetic cord factor from M. tuberculosis (trehalose 6,6'-dibehenate)-a novel adjuvant inducing both strong CMI and antibody responses. Biochim. Biophys. Acta 2005, 1718, 22-31. [CrossRef] [PubMed]

157. Ishikawa, E.; Ishikawa, T.; Morita, Y.S.; Toyonaga, K.; Yamada, H.; Takeuchi, O.; Kinoshita, T.; Akira, S.; Yoshikai, Y.; Yamasaki, S. Direct recognition of the mycobacterial glycolipid, trehalose dimycolate, by C-type lectin Mincle. J. Exp. Med. 2009, 206, 2879-2888. [CrossRef]

158. Schoenen, H.; Bodendorfer, B.; Hitchens, K.; Manzanero, S.; Werninghaus, K.; Nimmerjahn, F.; Agger, E.M.; Stenger, S.; Andersen, P.; Ruland, J.; et al. Cutting edge: Mincle is essential for recognition and adjuvanticity of the mycobacterial cord factor and its synthetic analog trehalose-dibehenate. J. Immunol. 2010, 184, 2756-2760. [CrossRef]

159. Werninghaus, K.; Babiak, A.; Gross, O.; Holscher, C.; Dietrich, H.; Agger, E.M.; Mages, J.; Mocsai, A.; Schoenen, H.; Finger, K.; et al. Adjuvanticity of a synthetic cord factor analogue for subunit Mycobacterium tuberculosis vaccination requires FcRgamma-Syk-Card9-dependent innate immune activation. J. Exp. Med. 2009, 206, 89-97. [CrossRef]

160. Lin, Y.; Wang, X.; Huang, X.; Zhang, J.; Xia, N.; Zhao, Q. Calcium phosphate nanoparticles as a new generation vaccine adjuvant. Expert Rev. Vaccines 2017, 16, 895-906. [CrossRef]

161. He, Q.; Mitchell, A.; Morcol, T.; Bell, S.J. Calcium phosphate nanoparticles induce mucosal immunity and protection against herpes simplex virus type 2. Clin. Diagn. Lab. Immunol. 2002, 9, 1021-1024. [CrossRef]

162. He, Q.; Mitchell, A.R.; Johnson, S.L.; Wagner-Bartak, C.; Morcol, T.; Bell, S.J. Calcium phosphate nanoparticle adjuvant. Clin. Diagn. Lab. Immunol. 2000, 7, 899-903. [CrossRef] [PubMed]

163. Smith, D.M.; Simon, J.K.; Baker, J.R., Jr. Applications of nanotechnology for immunology. Nat. Rev. Immunol. 2013, 13, 592-605. [CrossRef] [PubMed]

164. Jain, S.; O'Hagan, D.T.; Singh, M. The long-term potential of biodegradable poly (lactide-co-glycolide) microparticles as the next-generation vaccine adjuvant. Expert Rev. Vaccines 2011, 10, 1731-1742. [CrossRef] [PubMed] 
165. Kuroda, E.; Coban, C.; Ishii, K.J. Particulate adjuvant and innate immunity: Past achievements, present findings, and future prospects. Int. Rev. Immunol. 2013, 32, 209-220. [CrossRef] [PubMed]

166. Kuroda, E.; Ishii, K.J.; Uematsu, S.; Ohata, K.; Coban, C.; Akira, S.; Aritake, K.; Urade, Y.; Morimoto, Y. Silica crystals and aluminum salts regulate the production of prostaglandin in macrophages via NALP3 inflammasome-independent mechanisms. Immunity 2011, 34, 514-526. [CrossRef] [PubMed]

167. Ahn, S.; Lee, I.H.; Kang, S.; Kim, D.; Choi, M.; Saw, P.E.; Shin, E.C.; Jon, S. Gold nanoparticles displaying tumor-associated self-antigens as a potential vaccine for cancer immunotherapy. Adv. Healthc. Mater. 2014, 3, 1194-1199. [CrossRef]

168. Brinas, R.P.; Sundgren, A.; Sahoo, P.; Morey, S.; Rittenhouse-Olson, K.; Wilding, G.E.; Deng, W.; Barchi, J.J., Jr. Design and synthesis of multifunctional gold nanoparticles bearing tumor-associated glycopeptide antigens as potential cancer vaccines. Bioconjug. Chem. 2012, 23, 1513-1523. [CrossRef]

169. Kedersha, N.L.; Rome, L.H. Isolation and characterization of a novel ribonucleoprotein particle: Large structures contain a single species of small RNA. J. Cell Biol. 1986, 103, 699-709. [CrossRef]

170. Kickhoefer, V.A.; Poderycki, M.J.; Chan, E.K.; Rome, L.H. The La RNA-binding protein interacts with the vault RNA and is a vault-associated protein. J. Biol. Chem. 2002, 277, 41282-41286. [CrossRef]

171. Berger, W.; Steiner, E.; Grusch, M.; Elbling, L.; Micksche, M. Vaults and the major vault protein: Novel roles in signal pathway regulation and immunity. Cell. Mol. Life Sci. 2009, 66, 43-61. [CrossRef]

172. Buehler, D.C.; Marsden, M.D.; Shen, S.; Toso, D.B.; Wu, X.; Loo, J.A.; Zhou, Z.H.; Kickhoefer, V.A.; Wender, P.A.; Zack, J.A.; et al. Bioengineered vaults: Self-assembling protein shell-lipophilic core nanoparticles for drug delivery. ACS Nano 2014, 8, 7723-7732. [CrossRef]

173. Kar, U.K.; Jiang, J.; Champion, C.I.; Salehi, S.; Srivastava, M.; Sharma, S.; Rabizadeh, S.; Niazi, K.; Kickhoefer, V.; Rome, L.H.; et al. Vault nanocapsules as adjuvants favor cell-mediated over antibody-mediated immune responses following immunization of mice. PLoS ONE 2012, 7, e38553. [CrossRef]

174. Pino, O.; Martin, M.; Michalek, S.M. Cellular mechanisms of the adjuvant activity of the flagellin component $\mathrm{FljB}$ of Salmonella enterica Serovar Typhimurium to potentiate mucosal and systemic responses. Infect. Immun. 2005, 73, 6763-6770. [CrossRef] [PubMed]

175. Taylor, D.N.; Treanor, J.J.; Sheldon, E.A.; Johnson, C.; Umlauf, S.; Song, L.; Kavita, U.; Liu, G.; Tussey, L.; Ozer, K.; et al. Development of VAX128, a recombinant hemagglutinin (HA) influenza-flagellin fusion vaccine with improved safety and immune response. Vaccine 2012, 30, 5761-5769. [CrossRef] [PubMed]

176. Turley, C.B.; Rupp, R.E.; Johnson, C.; Taylor, D.N.; Wolfson, J.; Tussey, L.; Kavita, U.; Stanberry, L.; Shaw, A. Safety and immunogenicity of a recombinant M2e-flagellin influenza vaccine (STF2.4xM2e) in healthy adults. Vaccine 2011, 29, 5145-5152. [CrossRef] [PubMed]

177. Dos Reis, E.C.; Leal, V.N.C.; Soares, J.; Fernandes, F.P.; Souza de Lima, D.; de Alencar, B.C.; Pontillo, A. Flagellin/NLRC4 Pathway Rescues NLRP3-Inflammasome Defect in Dendritic Cells From HIV-Infected Patients: Perspective for New Adjuvant in Immunocompromised Individuals. Front. Immunol. 2019, 10, 1291. [CrossRef]

178. Lugrin, J.; Martinon, F. The AIM2 inflammasome: Sensor of pathogens and cellular perturbations. Immunol. Rev. 2018, 281, 99-114. [CrossRef]

179. Hobernik, D.; Bros, M. DNA Vaccines-How Far From Clinical Use? Int. J. Mol. Sci. 2018, 19, 3605. [CrossRef]

180. Heilig, R.; Broz, P. Function and mechanism of the pyrin inflammasome. Eur. J. Immunol. 2018, 48, $230-238$. [CrossRef]

181. Liston, A.; Masters, S.L. Homeostasis-altering molecular processes as mechanisms of inflammasome activation. Nat. Rev. Immunol. 2017, 17, 208-214. [CrossRef]

182. Stratmann, T. Cholera Toxin Subunit B as Adjuvant-An Accelerator in Protective Immunity and a Break in Autoimmunity. Vaccines 2015, 3, 579-596. [CrossRef] [PubMed]

183. Kayagaki, N.; Wong, M.T.; Stowe, I.B.; Ramani, S.R.; Gonzalez, L.C.; Akashi-Takamura, S.; Miyake, K.; Zhang, J.; Lee, W.P.; Muszynski, A.; et al. Noncanonical inflammasome activation by intracellular LPS independent of TLR4. Science 2013, 341, 1246-1249. [CrossRef] [PubMed]

184. Ruhl, S.; Shkarina, K.; Demarco, B.; Heilig, R.; Santos, J.C.; Broz, P. ESCRT-dependent membrane repair negatively regulates pyroptosis downstream of GSDMD activation. Science 2018, 362, 956-960. [CrossRef] [PubMed] 
185. Davis, H.L. Novel vaccines and adjuvant systems: The utility of animal models for predicting immunogenicity in humans. Hum. Vaccines 2008, 4, 246-250. [CrossRef]

186. Jesus, A.A.; Goldbach-Mansky, R. IL-1 blockade in autoinflammatory syndromes. Annu. Rev. Med. 2014, 65, 223-244. [CrossRef]

(c)

(C) 2020 by the authors. Licensee MDPI, Basel, Switzerland. This article is an open access article distributed under the terms and conditions of the Creative Commons Attribution (CC BY) license (http://creativecommons.org/licenses/by/4.0/). 